\title{
ZLOČIN GENOCIDA PRED MEĐUNARODNIM SUDOM U HAAGU
}

\author{
UDK: $343: 341.4$ \\ Izvorni znanstveni rad \\ Primljeno: 1.02. 2016.
}

\begin{abstract}
U ovoj raspravi najprije se razmatraju neka opća pitanja međunarodnoga prava vezana za zločin genocida. Njihovo nedovoljno ili nikakvo poznavanje uzrokom je brojnih nesporazuma glede sadržaja i domašaja sudskih odluka o tome najodvratnijem međunarodnom zločinu. Potom se ukratko izlažu odluke Međunarodnoga suda u Haagu u parnicama u kojima je SRJ, Srbija i Crna Gora ili sama Srbija bila stranka u postupku, bilo kao tužena strana ili tužiteljica. Radi se o parnici Bosne i Hercegovine protiv SRJ, potom o onoj u kojoj je SRJ tužila deset država članica NATO-a, te na koncu o parnici Hrvatske protiv SRJ. Nisu na isti način obrađene presude međunarodnih kaznenih tribunala za bivšu Jugoslaviju i za Ruandu koje se odnose na taj zločin. Na koncu se izlaže kratak zaključak iz kojega je razvidno zašto su te parnice, sve temeljene na članku IX. Konvencije o genocidu iz 1948., bile za države tužiteljice dugotrajne, skupe i na koncu neuspješne. Žrtve međunarodnih zločina nisu dobile nikakvu zadovoljštinu.
\end{abstract}

Ključne riječi: Actus reus, mens rea, dolus specialis, compétence de la compétence, presedani

\section{NEKA OPĆA PITANJA}

\section{Različita sudska tijela}

Dvije konačne presude Međunarodnoga suda protiv Srbije za genocid, najprije ona od 26. veljače 2007. u povodu tužbe Bosne i Hercegovine, te potom ona od 3. veljače 2014. temeljem tužbe Hrvatske, izazvale su neodobravanje javnosti. One nisu ispunile očekivanja žrtava zločina počinjenih na ovim prostorima. Neka od tih očekivanja bila su neopravdana jer proizlaze iz nepoznavanja funkcija i nadležnosti toga Suda, ali ima i navoda, napose u presudi iz 2007., koji zaslužuju ozbiljnu kritiku.

U oba se slučaja ponavlja zbrka u glavama onih koji smatraju da trebaju izraziti svoje mišljenje o svakom sudskom pravorijeku. Zbrka postoji ponajprije glede identiteta sudbenoga tijela u pitanju, za što makar djelomičnu krivnju nose hrvatski jezikoslovci. Naime, pod zbirnom imenicom „Haški sud“ kriju se čak tri sudbena tijela s veoma različitim ovlastima i funkcijama. Mnogi od onih koji raspravljaju o sudskim odlukama glede utvrđivanja i kažnjavanja međunarodnih zločina uopće nisu svjesni tih razlika. Neki čak misle da se radi o jednom sudu. 
Međunarodni sud (kod nas neprecizno nazivan „Međunarodnim sudom pravde“, kao da postoje sudovi krivde), ${ }^{1}$ jedan je od šest glavnih organa i formalno glavni sudski organ UN-a. On izriče pravdu u parnicama između država, ali se njegova nadležnost uvijek zasniva na pristanku suverenih država stranaka spora u pitanju. Bez prethodnog ili ad hoc danoga pristanka, nema nadležnosti toga Suda.

Međunarodni kazneni tribunal za bivšu Jugoslaviju, uz onaj za Ruandu koji djeluje u Arushi u Tanzaniji, jest ad hoc sudbeno tijelo stvoreno pravno obvezujućom rezolucijom Vijeća sigurnosti za sve države članice UN-a. ${ }^{2} \mathrm{Uz}$ prvostupanjska sudbena vijeća i jednoga zajedničkog Žalbenog vijeća, svaki od njih ima i Ured tužitelja koji samostalno obavljaju svoje ovlasti.

Napokon, (stalni) Međunarodni kazneni sud ima također sjedište u Haagu. ${ }^{3}$ On je osnovan Rimskim statutom iz 1998. godine kojemu države mogu a i ne moraju pristupiti. Ali temeljem ad hoc odluka Vijeća sigurnosti UN-a on može dobiti u nadležnost i kažnjavanje zločina počinjenih na području država nečlanica. ${ }^{4}$ I on ima Ured tužitelja kao zaseban organ. Hrvatska (još) nije bila strana niti jednoga predmeta pred tim Sudom.

Tako Međunarodni sud u svojoj praksi veoma restriktivno tumači svoju nadležnost u izricanju pravde državama. On troši gotovo dvije trećine svoga vremena na utvrđivanju te nadležnosti u parnicama koje mu se iznesu, a samo jednu trećinu na meritum spora nakon što tu svoju nadležnost utvrdi. Naprotiv, Tužiteljstvo Međunarodnoga kaznenog tribunala za bivšu Jugoslaviju izdavalo je uhidbene naloge prema svojoj veoma širokoj procjeni o krivnji osumnjičenika. Neki od njih su proveli više godina u zatvorskoj jedinici u Scheweningenu da bi konačnom presudom Žalbenoga vijeća bili oslobođeni. Ponekad je čak dolazilo do zamjene identiteta i uhićivane su krive osobe s istim imenom i prezimenom kao i pravi osumnjičenici. Nitko od njih nema pravo na odštetu jer se UN poziva na imunitet $\mathrm{u}$ tome pogledu.

1 Taj je izraz u nas nastao kao dosljedan prijevod naziva sudbenih tijela na francuskom, engleskom ili španjolskom jeziku: cour de justice, court of justice, corte de justicia. Na tim jezicima sam izraz „,cour ${ }^{6}$ ima više raznolikih značenja i potrebno ga je precizirati. Na slavenskim jezicima on je nepotreban jer je sud uvijek samo sud koji je pozvan da izriče pravdu. Tako se na ruskom taj organ naziva „Meždunarodnyj Sud Ob"edinennyh Nacij"“.

2 I obvezatna nadležnost tih dvaju tribunala proizlazi iz pristanka država članica UN-a koji su one dale kao stranke Povelje te Organizacije. Njezin članak 25. propisuje: „Članovi Ujedinjenih nacija suglasni su da prihvate i izvršavaju odluke Vijeća sigurnosti u skladu s ovom Poveljom." Vijeće sigurnosti usvojilo je statute tih dvaju kaznenih tribunala temeljem Glave VII. Povelje koja se odnosi na djelovanje u slučaju prijetnje miru, narušenja mira i čina agresije. Naime, počinjeni zločini u bivšoj SFRJ i u Ruandi smatraju se prijetnjom međunarodnom miru glede kojih je taj glavni organ UN-a nadležan donositi pravno obvezujuće odluke za sve države članice te svjetske organizacije.

3 Upravo da bi se istaknula razlika između privremenih sudbenih tijela stvorenih rezolucijama Vijeća sigurnosti i ovoga Suda koji je osnovan da bi djelovao stalno, oni prvi se na engleskom, francuskom, španjolskom i ruskom jeziku nazivaju ,tribunalima“. Iz istih razloga smatramo neophodnim da se taj naziv koristi i u nas, iako je on prije bio neuobičajen na hrvatskom jeziku.

4 Time prestaje potreba da se, poput za slučajeve bivše Jugoslavije i Ruande, osnivaju posebni tribunali u svrhu prevencije i kažnjavanja masovnih i teških zločina, a napose genocida. 
Zbrka između sudbenih tijela $\mathrm{s}$ toliko različitim nadležnostima redovito uzrokuje zbrku pri ocjenjivanju njihovih odluka. Uz to, javnost u svakoj državi sljednici bivše SFRJ vjeruje da su samo pripadnici njezine skupine bili žrtve međunarodnih zločina, dok su pripadnici neprijateljske strane bili većinom stvarni ili potencijalni zločinci koji ne zaslužuju milost.

*

\section{Zločini u nadležnosti različitih međunarodnih sudišta}

Od gornjega još se više mora voditi računa o nadležnosti glede kažnjavanja međunarodnih zločina i o pravu koje primjenjuje svako od tih sudbenih tijela.

Prema kriterijima iz općega međunarodnog prava, postoji mnoštvo međunarodnih zločina, ${ }^{5}$ ali svi oni nisu u nadležnosti postojećih međunarodnih sudišta. Piratstvo na otvorenom moru, ropstvo i trgovina robljem, međunarodni terorizam, trgovina drogom kao transnacionalni zločin i neka druga djela u nadležnosti su domaćih sudova i tiču se uzajamne suradnje zainteresiranih država. Djelotvornost u njihovu suzbijanju ovisi o toj međunarodnoj suradnji o čemu se sklapaju brojne konvencije.

Ovdje će biti riječi o međunarodnim zločinima koji su u nadležnosti međunarodnih sudišta, uz paralelnu nadležnost za većinu njih i domaćih sudova u državama. Pri tome, međunarodni kazneni tribunali i stalni Međunarodni kazneni sud u Haagu osnovani su radi kažnjavanja fizičkih osoba za njihovo počinjenje, dok je utvrđivanje odgovornosti država za zločin genocida povjereno Konvencijom iz 1948. u nadležnost Međunarodnoga suda u Haagu.

Međunarodni kazneni tribunal za bivšu Jugoslaviju (dalje: „Tribunal“) nadležan je, prema člancima 2. do 5. njegova Statuta, voditi kazneni postupak protiv pojedinaca osumnjičenih da su počinili neke od četiri skupine zločina: (i) teška kršenja Ženevskih konvencija iz 1949. godine (članak 2); (ii) kršenja zakonâ i običajâ rata (članak 3); (iii) genocid (članak 4); te (iv) zločine protiv čovječnosti (članak 5). Djela pod (i) i (ii) sastoje se od ratnih zločina.

Rimski statut propisao je nadležnost stalnoga Međunarodnog kaznenog suda u Haagu za zločin genocida, ratne zločine, zločine protiv čovječnosti, ali i za zločin agresije koji je naknadno definiran. Nadopune Rimskoga statuta o zločinu agresije, usvojene u Kampali u Ugandi 2010., još nisu stupile na snagu, tako da za kažnjavanje agresije danas nije nadležan niti jedan međunarodni sud ili tribunal. Ovdje se, dakle, sve radi o međunarodnim sudbenim tijelima koja su nadležna

5 Prema stavku 2. prijašnjega članka 19 u Nacrtu pravilâ o odgovornosti država koji je Komisija za međunarodno pravo usvojila, ali u konačnom tekstu napustila, „Međunarodno protupravno djelo koje proizlazi iz povrede od strane neke države međunarodne obveze koja je toliko bitna za zaštitu temeljnih interesa međunarodne zajednice da je njezina povreda priznata zločinom od te zajednice u njezinoj cjelini predstavlja međunarodni zločin." Iako ova definicija nije postala dio pozitivnoga međunarodnog prava, ona je važan putokaz pri određivanju konkretnih međunarodnih zločina. 
za kažnjavanje pojedinaca tj. fizičkih osoba, bilo kao nalogodavaca ili izvršitelja zločina u pitanju.

Kada je u pitanju odgovornost država za počinjenje gore spomenutih međunarodnih zločina, ona se može ugovoriti posebnim sporazumom između države pretpostavljene počiniteljice i države žrtve kojim one zajednički povjeravaju taj svoj spor nekom sudskom tijelu na presuđivanje. Uz to, same države nisu kazneno odgovorne, ali se njihova odgovornost prema općem međunarodnom pravu odnosi na svako međunarodno protupravno djelo. O tome više pojedinosti kasnije.

Osim za postojeće sporove, moguće je da države unaprijed sklope sporazume glede rješavanja svojih budućih sporova u sudskom ili arbitražnom postupku. Ali nije poznato da je to bilo kada obuhvatilo mogućnost kažnjavanja zločina agresije. Stoga valja dobro upamtiti da nema nikakvoga sudbenog tijela kojemu bi jedna država mogla tužiti drugu za zločin agresije. Vjerojatno će i u budućnosti to opstati, pa čak i ako Međunarodni kazneni sud u Haagu dobije nadležnost da kažnjava fizičke osobe za taj zločin.

\section{Domašaj presedana u praksi Međunarodnoga suda}

Za presude koje je Međunarodni sud izrekao zbog kršenja Konvencije o genocidu iz 1948. od velikoga je značaja bio autoritet presedana za sam taj Sud. Sud je najprije odlučivao u parnici koju je pokrenula Bosna i Hercegovina tužbom protiv Savezne Republike Jugoslavije (Srbije i Crne Gore) od 20. ožujka 1993. Potom je SRJ nastupila kao tužiteljica protiv deset država članica Sjevernoatlantskoga saveza (NATO-a) 29. travnja 1999. zbog bombardiranja svojega područja. Nedugo potom, 2. srpnja iste godine, Hrvatska je tužila SRJ.

Iako su se u nekima od tih tužbi isticale i druge osnove nadležnosti Međunarodnoga suda, u svim tim parnicama članak IX. te Konvencije imao je središnje mjesto. Za kasnije odluke o pokretanju i vođenju postupka trebale su biti značajne prijašnje odluke samoga Suda koje su se odnosile na tumačenje i primjenu te Konvencije, a napose na domašaj njegove nadležnosti predviđene $u$ njezinu članku IX.

Kada odlučuje o sličnim situacijama i o pravnim pravilima primjenjivima na njih, Međunarodni sud u Haagu poziva se u svojim odlukama na svoje prijašnje stavove i na one predratnoga Stalnog suda međunarodne pravde. Pri tome on ne čini nikakvu razliku između svojih presuda i savjetodavnih mišljenja. Sud nastoji u svojim odlukama koliko mu je moguće slijediti svoju prijašnju praksu, a ukoliko od nje ipak odstupi, nastoji te svoje promjene obrazložiti uvjerljivim pravnim razlozima. U svemu tome ne postoji načelo stare decisis kao obvezatno pravilo za 
kasnije slučajeve, kakvo se inače poštuje u praksi engleskih i američkih sudova. ${ }^{6}$ Ovdje se ne radi, makar ne otvoreno, o stvaranju novoga prava putem presedana, ali se prijašnjim sudskim odlukama pridaje visoki autoritet. ${ }^{7}$

U tome Međunarodni sud obično ne navodi stavove iz arbitražnih presuda i odluka drugih stalnih međunarodnih sudova. Ali je iz iskaza sudaca koji su odvojili mišljenja od većine vidljivo da je Sudu i ta praksa dobro poznata. Odnos toga Suda s ad hoc međunarodnim kaznenim tribunalima za bivšu Jugoslaviju i Ruandu posebno je pitanje koje ćemo opširnije razmotriti.

Stavovi Međunarodnoga suda u sporovima koji se odnose na tumačenje, primjenu i provedbu teksta Konvencije o genocidu iz 1948. godine od posebnoga su značaja. U stvari čitava ta praksa čini cjelinu jer se radi o tumačenju i primjeni iste konvencije. Kasnije pravorijeke teško je ispravno razumjeti bez poznavanja te cjeline.

Ali je još važnija činjenica da je teško ili gotovo nemoguće očekivati da će Sud u kasnije pokrenutoj parnici odlučivati temeljem bitno različitih kriterija od onih koje je već zauzeo u svojoj prijašnjoj praksi. Tako je i Hrvatska pri pokretanju svoje tužbe u 1999. mogla unaprijed s priličnom sigurnošću procijeniti je li imala izgleda da pred Sudom dokaže da se zločin genocida prema određenju iz članaka II. i III. Konvencije iz 1948. godine zbio i na njezinu području.

\section{Konvencija o genocidu iz 1948. godine}

Genocid je najodvratniji međunarodni zločin, ali je njega u sudskom postupku najteže dokazati. Konvencija o sprečavanju i kažnjavanju zločina genocida bila je usvojena rezolucijom Opće skupštine UN-a br. 260 od 9. prosinca 1948. godine. Stupila je na snagu 12. siječnja 1951. Do danas je 146 država postalo njezinim strankama. Sjedinjene Države postale su strankom te Konvencije 25. studenoga 1988., dakle četrdeset godina nakon njezina usvajanja, ${ }^{8}$ a Malta tek 6. lipnja 2014.

Bivša SFRJ ratificirala je tu Konvenciju 29. kolovoza 1950. i ona ju je po ugovornoj osnovi obvezivala od njezina stupanja na snagu, tj. od 12. siječnja 1951. Raspadom i nestankom jugoslavenske federacije, njezine države sljednice postale su strankama Konvencije o genocidu izjavama o njezinoj sukcesiji, i to tek nakon što je svaka od njih primljena u članstvo UN-a. Nakon što su 22. svibnja 1992.

6 Dio formule iz rimskoga prava koja u potpunosti glasi: „stare decisis et non quieta movere“ (držati se onoga što je odlučeno i ne remetiti ono što je ustanovljeno). U angloameričkom pravu prijašnje sudske odluke imaju obvezatnu snagu, osim ako su napuštene kasnijim odlukama viših sudova ili onih jednakoga ranga.

Sasvim je različito u domaćem i međunarodnom kaznenom pravu gdje je stvaranje novih kaznenih djela putem presedana ili temeljem analogije sa sličnim djelima izričito zabranjeno.

8 To, međutim, ne znači da zločini koji čine materijalni element genocida nisu i prije te zabrane bili posebna kaznena djela, poput ubojstva ili nanošenja teške tjelesne ili psihičke povrede pojedincu. Vidi dalje o genocidnoj namjeri. 
stekle taj uvjet, te su izjave dale: 6. srpnja Slovenija, 12. listopada Hrvatska i 25. prosinca te godine Bosna i Hercegovina. Potom ju je Makedonija dala 18. siječnja 1994., nakon što je bila primljena u članstvo UN-a 8. travnja prethodne godine. Sve do pada Slobodana Miloševića s vlasti u Beogradu, Savezna Republika Jugoslavija (Srbija i Crna Gora) pretendirala je na identitet i kontinuitet sa SFRJ, kakav je priznat Ruskoj Federaciji u odnosu na bivši SSSR. Ali taj zahtjev režima u Beogradu nije bio općenito priznat. Ipak, i taj neuvaženi zahtjev implicirao je da SRJ nije mogla osporavati svoj položaj stranke Konvencije o genocidu, i to još od siječnja 1951. godine.

Politički uvjet da i SRJ postane članicom UN-a bio je da se ona odrekne zahtjeva za kontinuitetom sa SFRJ. Tako je ona 1. studenoga 2000. postala članicom UN-a kao nova država i jednaka u pravima s Bosnom i Hercegovinom, Hrvatskom, Makedonijom i Slovenijom. Taj položaj naveo ju je da naknadno ustvrdi da je kao nova država nastala 27. travnja 1992., tj. s danom usvajanja Deklaracije predstavnika Skupština Srbije i Crne Gore u Beogradu, te da prije toga datuma nije mogla biti strankom Konvencije o genocidu, a ni strankom Statuta Međunarodnoga suda u Haagu.

Nakon što je 3. lipnja 2006. proglasila svoju neovisnost, Crna Gora je deklaracijom o sukcesiji postala strankom Konvencije o genocidu 23. listopada te godine. Tako među novim državama nastalima na prostoru bivše SFRJ jedino Kosovo još nije po ugovornoj osnovi stranka te Konvencije, a njegov se pristup teško može očekivati prije nego što ono bude primljeno u UN.

Članak IX. ove Konvencije ključan je za našu raspravu. On glasi:

„Sporovi među strankama ugovornicama o tumačenju, o primjeni i provedbi ove Konvencije, uključujući sporove što se odnose na odgovornost neke države za genocid ili bilo koje drugo djelo navedeno u članku III, iznijet će se pred Međunarodni sud na zahtjev jedne od stranaka u sporu.“

Konvencija o genocidu je, dakle, jedini ugovorni propis koji obvezuje više od stotinu država a kojim su njegove stranke pristale da ih neka druga država stranka može Međunarodnom sudu tužiti za kršenje njezinih odredaba. Valja zapamtiti da ne postoji nikakav sličan propis o sudskom ili arbitražnom rješavanju sporova glede odgovornosti država za počinjenje drugih međunarodnih zločina, a napose ne za zločin agresije. To značajno ograničenje u današnjem međunarodnom pravu nisu shvatili laici među političarima i novinarima bez pravne naobrazbe, ali ni svi oni sa završenim pravnim studijima. Među ovim posljednjima neki su zaboravili odgovarajuće lekcije iz međunarodnoga prava, ili su ih zapamtili ali ne znaju u praksi primijeniti ono što su možda davno učili. 


\section{Zaključak: kažnjivost počinitelja zločina agresije i genocida}

Da rezimiramo ono što smo prije izložili. Za zločin agresije ne postoji danas niti jedno međunarodno sudbeno tijelo kojemu bi država njegova žrtva ili nadležno tužiteljstvo mogli jednostrano uputiti tužbu, i to bilo da se radi o nekom kaznenom sudištu ili o Međunarodnom sudu. Istina je da Vijeće sigurnosti UN-a može temeljem Glave VII. Povelje proglasiti neku državu agresorom i poduzeti protiv nje i oružanu akciju. Ali svaka od država stalnih članica toga tijela (Sjedinjene Države, Ruska Federacija, Kina, Britanija ili Francuska), može svojim vetom spriječiti takvu odluku kada je ona sama umiješana u taj zločin ili kada štiti drugu državu od takvih optužbi. To je surova stvarnost nejednakosti država u međunarodnoj zajednici još od osnivanja UN-a u 1945. godini koju je formalnom revizijom teksta Povelje nemoguće ispraviti.

Osim toga, Vijeće sigurnosti izbjegava u svojoj praksi označiti neku državu agresorom čak kad je agresija očita. U tim situacijama ono se u svojim rezolucijama služi blažim izrazima ili blažom kvalifikacijom djela. Vjerojatno je u tome namjera da se očuvaju izgledi za političko rješenje krize pristankom svih strana u sukobu, uključujući i samoga agresora. To je stvarnost kada je u pitanju odgovornost država za zločin agresije.

Kada je u pitanju kaznena odgovornost pojedinaca za taj vrhunski međunarodni zločin koji utjelovljuje akumulirano zlo svega, izmjene Rimskoga statuta, usvojene u Kampali 2010. godine, trebaju se naknadno potvrditi nakon 1. siječnja 2017. godine, a važit će samo između onih država stranaka Rimskoga statuta koje ih prihvate. Ali, ako ove izmjene ikada stupe na snagu, teško će, ako ne i nemoguće, provoditi kazneni postupak u povodu zločina agresije bez blagoslova Vijeća sigurnosti.

Vijeće sigurnosti može rezolucijom prihvaćenom temeljem Glave VII. Povelje UN-a sâmo uputiti Tužitelju Suda neku ,situaciju“ kada smatra da je počinjena agresija ili neki drugi zločin iz nadležnosti Suda. Tada ne postoje nikakva ograničenja ratione loci i ratione personae koja mogu važiti u drugim situacijama, Ali takvu odluku može svojim vetom spriječiti svaka stalna članica toga organa. Ako je postupak pokrenut inicijativom neke države stranke ili Tužitelja proprio motu, Vijeće sigurnosti može od Suda zatražiti da ne otpočne istragu ili da je prekine na rok od 12 mjeseci. Ti se zahtjevi mogu ponavljati u nedogled.

Između pet stalnih članica toga tijela koje raspolažu pravom veta do sada su jedine Britanija i Francuska ratificirale Rimski statut iz 1998. godine. Time velike sile mogu u slučaju agresije spriječiti i kazneni postupak protiv odgovornih pojedinaca kad god im to odgovara. ${ }^{9}$

9 Vidi pojedinosti, V. Đ. Degan: „Odgovornost za zločin agresije u svim njezinim vidovima“, Rad Hrvatske akademije znanosti i umjetnosti 510, Društvene znanosti, knjiga 48, Zagreb, 2011., str. 271-279. 
Za razliku od agresije, kažnjavanje odgovornih pojedinaca za zločin genocida u nadležnosti je svih međunarodnih sudova i tribunala o kojima je ovdje riječ, i to dvaju ad hoc tribunala za bivšu Jugoslaviju i za Ruandu, te stalnoga Međunarodnog kaznenog suda. A članak IX. Konvencije o genocidu iz 1948. dopušta tužbe Međunarodnom sudu njezinih država stranaka protiv drugih stranaka. Ali, kako smo prije naglasili, ta se sudska nadležnost u sporovima o odgovornosti država odnosi samo na zločin genocida, a ne i za sve druge zločine koje opće međunarodno pravo takvima priznaje. Stoga je nadležnost međunarodnih kaznenih sudišta uvijek šira od one koju može imati Međunarodni sud.

Dakle, kada se radi o kažnjavanju zločina genocida, nadležnost kaznenih sudbenih tijela ustanovljenih radi kažnjavanja pojedinaca preklapa se s onom Međunarodnoga suda koji ustanovljuje odgovornost država kao subjekata međunarodnoga prava. Propisi međunarodnoga prava o odgovornosti država bitno su različiti od onih glede kaznene odgovornosti pojedinaca za međunarodne zločine. Ali je određenje toga zločina koje je propisano člancima I. do III. Konvencije iz 1948. uneseno bez bitnih izmjena u statute svih kaznenih sudbenih tijela, pa i u kazneno zakonodavstvo većine država.

I dok kaznena sudišta nisu ovlaštena dosuđivati odštetu žrtvama zločina, ukoliko bi Međunarodni sud svojom presudom utvrdio kršenje obveza tužene stranke iz te Konvencije, on bi nakon toga u posebnom postupku mogao povrijeđenoj državi dosuditi odštetu.

$*$

\section{Redoslijed usvajanja međunarodnih instrumenata glede odgovornosti za genocid}

Međunarodni kazneni tribunal u Haagu nadležan je za suđenje osobama koje se pretpostavljaju odgovornima za međunarodne zločine na području bivše Jugoslavije od 1991. godine. Taj je Tribunal dakle nadležan ratione temporis za zločine koji su se zbili od te godine pa nadalje. U 1991. godini došlo je do opsade Dubrovnika i Vukovara u Hrvatskoj. Najteži zločini koje je počinila srpska strana dogodili su se čak prije 8. listopada te godine, kada je Hrvatska raskinula posljednje veze $s$ onim što je još bilo privremeno preostalo od jugoslavenske federacije (SFRJ). Ali do pada Vukovara i zločina u njemu došlo je nakon toga datuma, i to 20. studenoga i kasnije.

Do toga vremena još nisu bila kodificirana sva pravila o odgovornosti pojedinaca u kaznenom postupku, niti je Komisija za međunarodno pravo UN-a dovršila svoj Nacrt pravilâ o odgovornosti država. Ti akti, važni za našu raspravu, donosili su se sljedećim redoslijedom:

Rezolucijom 827. od 25. svibnja 1993. Vijeće sigurnosti usvojilo je Statut Međunarodnoga kaznenog tribunala za bivšu Jugoslaviju. Taj Tribunal počeo je sa svojim radom 18. studenoga te godine, a prva njegova konačna presuda u 
slučaju Erdemović izrečena je 29. studenoga 1996. Prije toga u presudi od 11. srpnja 1996. Međunarodni sud se proglasio nadležnim u postupku povodom tužbe Bosne i Hercegovine protiv SRJ za zločin genocida. Dana 17. srpnja 1998. bila je dovršena izrada teksta Rimskoga statuta Međunarodnoga kaznenog suda sa sjedištem u Haagu koji je počeo djelovati 1. srpnja 2002. I konačno, nakon rada koji je otpočeo još 1956. godine, 9. kolovoza 2001. Komisija za međunarodno pravo dovršila je i predala Općoj skupštini UN-a Nacrt pravila o odgovornosti država za međunarodno protupravna djela.

Svih ovih akata važnih za međunarodno pravo dakle još nije bilo kada je Bosna i Hercegovina 20. ožujka 1993. podnijela Međunarodnom sudu tužbu protiv SRJ za genocid, pa ni 2. srpnja 1999. kada je takvu tužbu podnijela Hrvatska. Ali su presude o meritumu tih sporova od 26. veljače 2007. i od 3. veljače 2015. bile široko zasnovane na pravnim pravilima koja su tim instrumentima naknadno kodificirana. ${ }^{10} \mathrm{U}$ tim aktima najvažnija su određenja odgovornosti pojedinaca, odnosno države, za međunarodne zločine i napose za genocid.

$*$

\section{Osobna kaznena odgovornost pojedinaca prema Rimskom statutu}

U pogledu kaznene odgovornosti fizičkih osoba postoji maksima u općem kaznenom pravu koja ima svoje korijene u rimskom i srednjovjekovnom kanonskom pravu, a koja glasi: ,,actus non facit reum, nisi mens sit rea“ (počinjeno djelo ne čini krivca ako svijest nije skrivljena). Stoga, uz materijalni element zločina u pitanju (actus reus), zabranjeno djelo mora biti počinjeno uz određenu svijest (mens rea).

Jedna od značajnih praznina u statutima međunarodnih kaznenih tribunala za bivšu Jugoslaviju i za Ruandu jest što nisu unaprijed predvidjeli cjeloviti skup općih načela kaznenoga prava, koje, naprotiv, sadrži opći dio kaznenih zakona u zemljama s kodificiranim pravom. Niti se Tribunal za bivšu Jugoslaviju nije potrudio da sva ta načela naknadno kodificira u svome Pravilniku o postupku i dokazima nakon što je počeo s radom. O pitanjima krivnje optuženika odlučivalo se od slučaja do slučaja, a to je proizvodilo neujednačenu praksu ponekad sumnjive naravi. Ta su pravila prvi put na uspješan način i cjelovito kodificirana Rimskim statutom iz 1998. godine.

Najprije o materijalnom elementu zločina, tj. o njegovu actus reus. Svaki zločin mora biti unaprijed definiran i za njega propisan raspon sankcija, i to bilo u kaznenom zakonodavstvu države u pitanju ili u statutu nadležnoga međunarodnog kaznenog sudišta. Ukoliko to nije slučaj i ako se pojedinca kažnjava za djelo koje

10 Tu se nije radilo o povredi načela nullum crimen sine lege, i to zbog toga što su naknadno kodificirana načela kaznenoga postupka u pitanju u stvari štitila i optuženika od samovolje sudaca. Povrede je bilo kada je npr. Tribunal u svoju praksu uveo zločin zajedničkoga zločinačkog pothvata koji statut ni jednoga međunarodnog kaznenog sudišta ne predviđa. 
nije pisanim propisom unaprijed zabranjeno, to predstavlja povredu načela nullum crimen sine lege. Naime, u kaznenom pravu zabranjena je analogija sa sličnim djelima.

Za svrhe ove rasprave još je značajniji članak 30. Rimskoga statuta koji uz actus reus sadrži i odredbu o psihološkom (mentalnom) elementu krivnje (mens rea). Taj propis glasi:

\section{„Članak 30: Krivnja}

1. Osim ako nije drukčije propisano, počinitelj je kazneno odgovoran i podliježe kažnjavanju za djelo iz nadležnosti Suda samo ako su ostvarena njegova posebna obilježja uz namjeru i saznanje.

2. Za potrebe ovoga članka, namjera počinitelja obuhvaća:

(i) u odnosu na ponašanje, htijenje počinitelja da se u njemu angažira;

(ii) u odnosu na posljedicu, htijenje počinitelja da ju svojim ponašanjem prouzroči ili je svjestan da će ona nastupiti prema redovitom tijeku događaja.

3. Za potrebe ovoga članka, saznanje obuhvaća spoznaju osobe da postoji neka okolnost ili da će njezina posljedica nastupiti u redovitom tijeku događaja. Izrazi "znati“ i ,saznanje“ tumačit će se na isti način."

Namjera i saznanje (intent and knowledge; intention et connaissance) glavni su sastojci „umišljaja“ u njegovu voljnom i spoznajnom (kognitivnom) smislu. Namjera osumnjičenog počinitelja postoji: (i) u odnosu na njegovo ponašanje, njegovo htijenje da se u zločinu angažira; (ii) a u odnosu na posljedicu, njegovo htijenje da je prouzroči ili njegovo saznanje da će ona nastupiti „u redovitom tijeku događaja“.

Ali ukupnost tih zahtjeva iz članka 30. posredno isključuje „objektivnu kaznenu odgovornost" (strict liability) počinitelja za posljedice počinjenoga djela u odsutnosti njegove krivnje. Stoga valja zaključiti da Rimski statut isključuje odgovornost te naravi, koja, uostalom, nije svojstvena općemu kaznenom pravu. ${ }^{11}$

Nehaj osumnjičenika, pa čak i njegovo propuštanje (nečinjenje), nisu predviđeni u samome članku 30, ali se tamo navodi da oni mogu biti posebno propisani. ${ }^{12}$ Drukčije od članka 30., propisano je u članku 28. Rimskoga statuta. Vojni zapovjednik ili nadređena (politička) osoba bit će kazneno odgovorna za zločine koje su počinile snage pod njezinom vlašću ili zapovjedništvom, i to između ostaloga kao

${ }_{11}$ Vidi opširnije o krivnji optuženika u V. Đ. Degan, B. Pavišić, Međunarodno kazneno pravo, str. 443-470, napose na str. 444-450. Vidi još opširnije Albin Eser: „,Mental elements - mistake of fact and mistake of law", u A. Cassese, P. Gaeta, J. R. W. D. Jones: The Rome Statute of the International Criminal Court, A Commentary, Oxford, 2002., Volume I, 889-934.

12 Podrazumijeva se da je samome Sudu prepušteno da o svjesnom nehaju, kao blažemu obliku krivnje, odlučuje od slučaja do slučaja čak i izvan propisa Statuta. Ali se isto ne može zaključiti kada je u pitanju nesvjesni nehaj počinitelja. Vidi V. Đ. Degan, B. Pavišić: op. cit., str. 444-447. Međutim, namjerno neuvrštenje u Rimski statut opće odredbe da se sâmo kazneno djelo može počiniti uz činjenje i propuštanjem (osim kada Statut to propiše), ima po našemu mišljenju dalekosežnije posljedice. Vidi o tome u sljedećoj bilješci. 
rezultat njezina propusta da poduzme sve nužne i razumne mjere u njezinoj moći da ih spriječi ili suzbije. ${ }^{13}$

Propisi o namjeri i saznanju nastali su napose u američkom kaznenom pravu. Oni se sasvim ne poklapaju s „umišljajem i nehajem“ iz europskoga kontinentalnog kaznenog prava. Te suptilne razlike moraju dobro poznavati svi oni koji zastupaju optuženike pred međunarodnim kaznenim sudištima ukoliko žele biti uspješni.

*

\section{Elementi međunarodno protupravnoga djela država u Nacrtu pravilâ Komisije za međunarodno pravo}

Sada će biti riječi o elementima međunarodno protupravnoga djela neke države za koje ona može biti prema međunarodnom pravu odgovorna. Unatoč nekim tendencijama kada su u pitanju zločini međunarodnoga terorizma, ${ }^{14}$ odgovornost države nije kaznene naravi. Krivnja počinitelja nije osnova odgovornosti države. Kao takva, ta je odgovornost, da tako kažemo, „objektivne naravi“, ali to ne podrazumijeva objektivnu odgovornost (strict liability) za sve posljedice počinjenoga djela, osim ukoliko je predviđena specifičnim pravilima međunarodnoga prava na snazi ili je države posebno ugovore.

Najprije o pravilima koja se odnose na državu počiniteljicu bilo kojega međunarodno protupravnoga djela. U tome pogledu članak 2. Nacrta pravila koji je usvojila Komisija za međunarodno pravo s njegovim naslovom glasi:

„Elementi međunarodno protupravnoga djela države:

Međunarodno protupravno djelo neke države postoji kada je ponašanje koje se sastoji u činjenju ili nečinjenju:

(a) pripisivo toj državi temeljem međunarodnoga prava; i

(b) predstavlja povredu neke međunarodne obveze te države.“

Dakle, međunarodno protupravno djelo (uključivši tu, naravno, i sve priznate međunarodne zločine) može se sastojati kako u činjenju tako i u nečinjenju (propuštanju). Slučajevi u kojima je međunarodna odgovornost neke države bila prizivana na temelju propuštanja njezinih organa u najmanju su ruku jednako brojni onima uslijed djela činjenja. Stoga kada je u pitanju odgovornost države propuštanje nije neki blaži oblik u odnosu na činjenje.

\footnotetext{
13 Neuvrštavanje općega propisa o kaznenoj odgovornosti uslijed propuštanja zapravo isključuje takvu odgovornost vojnih zapovjednika mirovnih misija i njihovih politički nadređenih uslijed nesprečavanja čak i najstrašnijih i najmasovnijih zločina koje počini neka strana u sukobu, poput onih u Bosni i Hercegovini i u Ruandi. Vidi ibid., str. 471-472.

${ }_{14}$ To je došlo do izražaja kada je postalo jasno da je talibanski režim u Afganistanu podržavao teroristički napad Al'Qaide 11. rujna 2001. u Sjedinjenim Državama. Vijeće sigurnosti usvojilo je već 28. rujna iste godine dalekosežnu pravno obvezujuću rezoluciju 1373 (2001.) o mjerama protiv međunarodnoga terorizma, a napose protiv financiranja terorističkih čina. Ubrzo su nakon toga početkom listopada te godine Sjedinjene Države i Britanija oružanom intervencijom svrgnule talibane u toj zemlji.
} 
Glede zahtjeva pod (b), materijalni se element sastoji od povrede neke međunarodne obveze ponašanjem bilo kojega organa države u pitanju, „,bilo da taj organ vrši zakonodavnu, izvršnu, sudbenu ili druge funkcije, bez obzira na njegovu prirodu organa središnje vlasti ili teritorijalne cjeline u državi“ (članak 4(1)). Povreda međunarodne obveze države postoji ,kada djelo te države nije u skladu s onim što ta obveza od nje zahtijeva, bez obzira na njezino porijeklo ili prirodu“ (članak 12). Stoga kada je u pitanju međunarodno protupravno djelo neke države ne postoji „zapovjedna odgovornost“. Država je odgovorna za čine i propuste pripisive svim njezinim organima u hijerarhiji, od glavara države do najniže rangiranoga vojnika, policajca ili drugog djelatnika. ${ }^{15}$

Osnova tih obveza koje se mogu prekršiti postavljena je, dakle, veoma široko. Kada je u pitanju odgovornost država, u općemu međunarodnom pravu ne postoji ništa slično načelu nullum crimen sine lege iz kaznenoga prava. Međutim, osim za genocid, u međunarodnoj zajednici ne postoji nikakav obvezatan sudski ili arbitražni postupak rješavanja međudržavnih sporova glede takvih kršenja. Država koja sebe smatra žrtvom nekoga međunarodno protupravnoga djela druge države nema na raspolaganju nikakvo sudbeno tijelo kojemu bi mogla podnijeti jednostranu tužbu i tim putem ishoditi pravdu za sebe.

Članci 4. do 11. predviđaju precizne i iscrpne odredbe o pripisivosti nekoga ponašanja državi, ${ }^{16}$ a članci 16. do 18 . uređuju odgovornost države za djelo druge države. ${ }^{17}$ Ta mnogobrojna pravila glede pripisivosti u neku ruku nadomještaju ono što čini mentalni element počinitelja međunarodnoga kaznenoga djela u osobnom svojstvu.

*

\section{Genocidna namjera (dolus specialis)}

Sve gore izloženo predstavlja opće propise međunarodnoga prava. Članak 55. Pravilâ o odgovornosti država predviđa da se gornji opći propisi ne primjenjuju „u slučajevima i u mjeri u kojoj su uvjeti postojanja nekoga međunarodno protupravnog djela, ili sadržaj, ili izvršenje međunarodne odgovornosti neke države uređeni posebnim pravilima međunarodnoga prava“" (lex specialis). ${ }^{18}$

Drukčije je upravo propisano u članku II. Konvencije o genocidu koji izričito predviđa da se sva tamo zabranjena djela moraju počiniti „, namjerom da se u

15 Vidi više pojedinosti o odgovornosti države u V. Đ. Degan: Međunarodno pravo (treće izdanje), Školska knjiga Zagreb, 2011., str. 346-385, napose str. 349-351, 353-361. Također, James Crawford: The International Law Commission's Articles on State Responsibility, Cambridge Univ. Press, 2002., pp. 81-85; 91-144.

16 Vidi prikaz tih odredbi - ibid., str. 353-359.

17 Ibid., str. 359-361.

18 Vidjeli smo da je sličan izuzetak izričito predviđen i na početku članka 30. Statuta Međunarodnoga kaznenog suda u Haagu. I odredbe o krivnji iz toga članka primjenjuju se ,/o/sim ako nije drukčije propisano“" 
cijelosti ili djelomično uništi neka nacionalna, etnička, rasna ili vjerska skupina“. Ako tijekom postupka država tužiteljica ne dokaže tu posebnu ili specifičnu namjeru tužene države, koju je Međunarodni sud nazvao „dolus specialis“, nije u pitanju genocid nego se može raditi o nekom drugom međunarodnom zločinu, najčešće o zločinu protiv čovječnosti ili o ratnom zločinu.

Članak 4. Statuta Međunarodnoga kaznenog tribunala za bivšu Jugoslaviju sadrži istu tu odredbu, uključujući onu o „dolus specialis“. Ali dok je taj Tribunal nadležan za kažnjavanje, uz genocid, triju drugih međunarodnih zločina, Međunarodni sud nije jer oni nisu predviđeni u Konvenciji o genocidu iz 1948. godine i stoga nisu pokriveni njezinim člankom IX.

Slijede prva tri članka Konvencije o genocidu koji taj međunarodni zločin čine posebnim u odnosu na sve druge zločine prema međunarodnom pravu, i napose $u$ odnosu na ostala međunarodno protupravna djela:

Članak I. „Stranke ugovornice potvrđuju da je genocid, bez obzira na to je li izvršen u vrijeme mira ili u vrijeme rata, zločin prema međunarodnom pravu; one se obvezuju da će ga sprečavati i kažnjavati.“

U izvršenju te pravne obveze sprečavanje i kažnjavanje genocida povjereno je u nadležnost svih međunarodnih kaznenih sudišta koja su osnovana nakon usvajanja te Konvencije u 1948. godini. I u odnosu na druge zločine predviđene u njihovim statutima, genocid je moguće počiniti u doba mira, kao i u svim vrstama oružanih sukoba, nemeđunarodnim i međunarodnima.

Članci II. I III. propisuju actus reus zločina genocida, dok navod u članku II. koji smo označili kurzivom predstavlja njegov mens rea:

Članak II. „U ovoj Konvenciji genocid znači bilo koje od sljedećih djela počinjeno s namjerom da se u cijelosti ili djelomično uništi neka nacionalna, etnička, rasna ili vjerska skupina:

(a) ubojstvo članova skupine;

(b) nanošenje teške tjelesne ili psihičke povrede članovima skupine;

(c) namjerno podvrgavanje skupine takvim uvjetima života koji bi trebali dovesti do njezinoga potpunog ili djelomičnog uništenja;

(d) nametanje takvih mjera kojima se želi spriječiti rađanje u okviru skupine;

(e) prisilno premještanje djece iz jedne skupine u drugu. “19

Članak III. „Kažnjiva su ova djela:

(a) genocid;

(b) urota kojoj je cilj genocid;

(c) neposredno i javno poticanje na genocid;

19 U biti na isti način genocid je definiran i u članku 156. hrvatskoga Kaznenog zakona usvojenog u 1997. godini. Vidi iscrpan komentar toga propisa u V. Đ. Degan, B. Pavišić: Međunarodno kazneno pravo, str. 230-233. 
(d) pokušaj da se izvrši genocid;

(e) suučesništvo u genocidu. “20

\section{Savjetodavno mišljenje Međunarodnoga suda iz 1951. godine}

Gornja su objašnjenja nužna za ispravno razumijevanje domašaja presuda Međunarodnoga suda i Kaznenoga tribunala za bivšu Jugoslaviju o Konvenciji o genocidu iz 1948. godine. Ali je već u 1950. izbio spor o dopustivosti rezervi na tu Konvenciju jer njezin tekst o tome ne sadrži nikakve propise. Naime, zemlje tadašnjeg istočnoga bloka bile su voljne postati strankama Konvencije o genocidu, ali se nisu htjele obvezati njezinim člankom IX. glede nadležnosti Međunarodnoga suda u slučaju sporova o njezinu tumačenju, primjeni i provedbi, uključujući sporove o odgovornosti neke države stranke za počinjenje toga zločina.

$\mathrm{O}$ tome je u međunarodnoj praksi do tada vladalo načelo apsolutnoga integriteta ugovora. Rezerve se nisu dopuštale osim ako ih je ugovorni tekst predviđao ili su ih sve postojeće stranke naknadno odobrile. Opća skupština zatražila je o tome pitanju savjetodavno mišljenje od Međunarodnoga suda u Haagu. U savjetodavnom mišljenju od 28. svibnja 1951. o Rezervama na Konvenciju o sprečavanju i kažnjavanju zločina genocida Sud se u tim slučajevima opredijelio za dopustivost rezervi i taj je stav potom prevladao u međunarodnoj praksi. ${ }^{21}$

To savjetodavno mišljenje još je važnije zbog zaključaka Suda o genocidu kao međunarodnom zločinu i o njegovim pogubnim posljedicama po čitavo čovječanstvo. Navodimo o tome zaključak Suda koji se otada često citira u znanosti i praksi:

„Porijeklo Konvencije ukazuje na namjeru Ujedinjenih nacija da osude i kazne genocid kao „zločin prema međunarodnom pravu“ koji podrazumijeva uskratu prava na opstanak čitavim ljudskim skupinama, uskratu koja šokira savjest čovječanstva i rezultira velikim gubicima za čovječanstvo i koja je u isto vrijeme suprotna moralnom pravu i duhu i ciljevima Ujedinjenih nacija (rezolucija Opće skupštine 96 (I), 11. prosinca 1946.). Prva posljedica koja proizlazi iz te koncepcije jest da su načela koja su u osnovi Konvencije načela priznata od civiliziranih naroda koja obvezuju države čak izvan svih ugovornih odnosa. Druga je posljedica univerzalni karakter kako osude genocida tako i međunarodne suradnje „da bi se čovječanstvo oslobodilo tog groznog zla“ (preambula Konvencije). Stoga je

20 I kažnjavanje djelâ iz članka III. Konvencije iz 1948. predviđeno je u istom tekstu u članku 4. Statuta Tribunala za bivšu Jugoslaviju, kao i u članku 2. Statuta Tribunala za Ruandu. Slično je uređeno i u Rimskom statutu Međunarodnoga kaznenog suda.

${ }_{21}$ Nalazi Suda iz toga savjetodavnoga mišljenja kodificirani su potom u članku 20. Bečke konvencije o pravu ugovora iz 1969., koje danas nitko u svijetu ne osporava. 
namjera kako Opće skupštine tako i ugovornih stranaka da Konvencija o genocidu ima univerzalni domašaj.“22

Dakle, genocid je zločin sam po sebi i po svojim učincima, a ne u prvom redu stoga što ga je neki međunarodni instrument proglasio zabranjenim. On je suprotan moralnom pravu, a njegovu zabranu priznaju svi civilizirani narodi.

Gornji su motivi bili razlogom što se značajan broj država obvezao Konvencijom iz 1948. kao ugovornim propisom, uključujući tu i njezin članak IX. Javnost u tim zemljama, uključujući i onu u bivšoj Jugoslaviji, jednostavno nije vjerovala da se taj grozni zločin može u budućnosti dogoditi na njihovu području i da će najodgovornijim civilnim i vojnim vođama njihovih država biti suđeno kao osumnjičenim počiniteljima.

Ali su krvavi raspad Jugoslavije i politika stvaranja Velike Srbije doveli do zločina protiv čovječnosti i ratnih zločina u masovnim razmjerima, pri čemu su se sukobljene strane međusobno optuživale i za genocid. Na nesreću žrtava, to je obogatilo međunarodnu sudsku praksu o tome zločinu i odgovornosti za njega, što je predmet ove analize. ${ }^{23}$

*

\section{Tri sporna pitanja u parnicama o genocidu}

U nastavku ćemo dati sintetičan opis odluka Međunarodnoga suda u trima odvojenim cjelinama, i to prema redoslijedu najprije iz parnice temeljem tužbe Bosne i Hercegovine protiv Srbije, potom one SRJ protiv zemalja NATO-a, te na koncu Hrvatske protiv Srbije. Pri tome ćemo se koncentrirati na tri točke koje su se tijekom tih postupaka pokazale spornima:

(a) Prva se točka tiče identiteta tužitelja. Bosna i Hercegovina podigla je u ožujku 1993. tužbu Sudu protiv Savezne Republike Jugoslavije (Srbije i Crne Gore). Ta se složena država 4. veljače 2003. transformirala u labavi savez „Srbije i Crne Gore", sve od odvajanja Crne Gore 3. lipnja 2006. kada je prestao postojati. Srbija je izjavom o sukcesiji preuzela odgovornost bivše države u ovom postupku, i to je Sud prihvatio (vidi dalje).

Do pada Slobodana Miloševića s vlasti u Beogradu 7. listopada 2000. ta država pretendirala je na identitet i kontinuitet s bivšom Socijalističkom Federativnom Republikom Jugoslavijom (SFRJ) na umanjenom prostoru. Nakon toga, pod pritiskom međunarodne zajednice, SRJ je 1. studenoga te godine bila primljena $\mathrm{u}$

22 I. C. J. Reports 1951, p. 23. Iz ovoga navoda proizišao je kasniji stav Međunarodnoga suda u presudi Barcelona Traction iz 1970. o obvezama erga omnes. Sve aspekte te vrste obveza obradili smo u raspravi V. D. Degan: „The Scope and Patterns of Erga Omnes Obligations in International Law“, Cursos Euro-Mediterraneos Bancaja de Derecho Internacional, Volumen X, Castellon, 2006., pp. 271-371.

23 Ovdje se nećemo baviti genocidom u afričkoj državi Ruandi u kojemu je u kratkom vremenskom razmaku između 6. travnja i 17. srpnja 1994. bilo pobijeno između pola milijuna i 800.000 ljudi. 
članstvo UN-a kao nova država, jednaka u pravima s ostalim državama sljednicama bivše SFRJ: s Bosnom i Hercegovinom, Hrvatskom, Makedonijom i Slovenijom.

Ali je u tome novom položaju SRJ ustvrdila da ona do 27. travnja 1992. nije mogla biti, niti je bila stranka Statuta Međunarodnoga suda, a ni stranka Konvencije o genocidu. Na toj osnovi odbijala je svu odgovornost za zločine bivše „Jugoslovenske narodne armije“ i paravojnih srpskih snaga počinjene u Hrvatskoj i Bosni i Hercegovini.

Međunarodni se sud u toj situaciji nije najbolje snalazio, a pokazalo se da ni pravna služba UN-a nije bila na visini svojih zadataka. Sud je u pojedinim slučajevima donosio kontradiktorne zaključke, što nije pridonijelo njegovu ugledu.

(b) Kako smo prije objasnili, isključiva osnova za nadležnost Međunarodnoga suda - toga glavnog organa UN-a - ležala je u članku IX. Konvencije o genocidu iz 1948. Jedino ukoliko bi neka država stranka te Konvencije bila u stanju dokazati da je tužena stranka kršila ugovorne odredbe iz nje, a napose one iz njezinih članaka II. i III, imala bi izgleda da temeljem svoje tužbe dobije presudu u svoju korist.

Države koje su bile žrtve napada SRJ i paravojnih snaga pod njezinim utjecajem nastojale su proširiti tu osnovu nadležnosti Suda, i to na zločine agresije, na posljedice etničkoga čišćenja, te na sve zločine protiv čovječnosti i ratne zločine koji su bili počinjeni u masovnim razmjerima.

Sud je od početka odbacivao te pokušaje i upozoravao je stranke da će se strogo držati članka IX. Konvencije i njezinih ostalih odredbi. Unatoč tim upozorenjima, u Bosni i Hercegovini stvaralo se javno mnijenje da će Međunarodni sud svim žrtvama agresije i etničkoga čišćenja dosuditi odštetu na račun Vlade u Beogradu u milijardama dolara. U Hrvatskoj se nisu obećavale milijarde, ali se isticalo da je veoma važno pred Sudom dokazati da je Srbija bila agresor u ratu protiv Hrvatske i da sama Hrvatska kao država nije nastala na zločinu.

Međunarodni sud nije u svojim presudama dosudio nikakvu odštetu žrtvama počinjenih zločina, ali su obje države tužiteljice same sebe oštetile za velike iznose na teret svojih proračuna, a na ime troškova postupka i napose plaćanja skupih usluga stranim odvjetnicima. Bilo bi razumnije neposredno udijeliti te izgubljene iznose žrtvama zločina, pa i kada se nije radilo o žrtvama genocida.

(c) Samo su parnice po tužbama Bosne i Hercegovine i Hrvatske protiv SRJ, tj. Srbije, završene izricanjem konačnih presuda o meritumu. I te su presude razočarale žrtve zločina i javno mnijenje jer su očekivanja bila pretjerana.

Ako ne za žrtve zločina, ti pravorijeci ipak su dragocjeni za buduću međunarodnu praksu i za znanost. Sud je savjesno razmotrio sve navode tužbi o počinjenim masovnim zločinima i potom je ocjenjivao je li ispunjen uvjet o actus reus za genocid iz članka II, ili neka druga osnova odgovornosti tužene države za sudjelovanje u zločinu iz članka III. Konvencije. Ako je zaključak bio pozitivan, Sud je ocjenjivao je li tužitelj u postupku dokazao genocidnu namjeru (mens rea) počinitelja u izvršenju tih groznih zločina. ${ }^{24}$

24 U tome sklopu ukazat će se na značaj nalaza o genocidnoj namjeri iz presuda Međunarodnoga kaznenog tribunala za bivšu Jugoslaviju, i inače na odnos Međunarodnoga suda i toga Tribunala. 
Možemo odmah navesti da je parnica po tužbi Bosne i Hercegovine otpočela 20. ožujka 1993., a da je okončana presudom o meritumu 26. veljače 2007. Tužba Hrvatske protiv iste tužene strane za kršenje iste Konvencije iz 1948. podnesena je Sudu 2. srpnja 1999., a konačna je presuda izrečena 3. veljače 2015. Kroz to dugačko razdoblje parničenja potrošena su ogromna financijska sredstva i uložen je veliki intelektualni napor da bi na koncu u svojim presudama Međunarodni sud ustanovio da jedino masakr u Srebrenici iz srpnja 1995. ispunjava uvjete zločina genocida iz Konvencije iz 1948. Ali ni u tome slučaju žrtve toga zločina ili njihovi nasljednici nisu dobili nikakvu materijalnu odštetu.

\section{Metamorfoza pravnoga položaja Savezne Republike Jugoslavije (Srbije i Crne Gore)}

Nakon raspada Sovjetskoga Saveza koncem 1991., niti režim u Beogradu nije više mogao ignorirati novonastalo stanje na Balkanu. Dana 27. travnja 1992. predstavnici zajedničkoga zasjedanja Skupštine SFRJ, te skupština Srbije i Crne Gore usvojili su zajedničku Deklaraciju. U njoj su naveli da Savezna Republika Jugoslavija produžuje državnu, međunarodnopravnu i političku osobnost (personalitet) Socijalističke Federativne Republike Jugoslavije i da će ona strogo poštovati sve obveze koje je SFRJ u prošlosti preuzela na međunarodnom planu. Tamo je također navedeno da SRJ neće ometati novonastale države da se učlane u međunarodne institucije, napose u UN i njihove specijalizirane ustanove. Prema toj Deklaraciji, SFRJ je pod djelomično izmijenjenim imenom i na umanjenom prostoru trebao kao ista država i dalje postojati.

Nasuprot tom zahtjevu za identitetom, Badinterova Arbitražna komisija u Mišljenju br. 8 od 4. srpnja 1992. zaključila je da je proces raspada SFRJ okončan i da valja ustanoviti da SFRJ više ne postoji. Rezolucija Vijeća sigurnosti UN-a 777 od 19. rujna 1992. potvrdila je u svojoj preambuli taj nalaz. Opća skupština u rezoluciji 47/I, od 22. rujna koja je uslijedila, također je u svojoj preambuli potvrdila taj nalaz i propisala je da SRJ treba tražiti svoje primanje u članstvo UN-a. Ali najkontroverzniji je bio posljednji zaključak da SRJ „neće sudjelovati u radu Opće skupštine“. Kasnije je ta zabrana proširena i na njezino sudjelovanje u Gospodarskom i socijalnom vijeću.

Tu nelogičnu situaciju koju su stvorili diplomati pokušali su razriješiti stalni predstavnici Bosne i Hercegovine i Hrvatske u UN-u. Oni su 25. rujna 1992. uputili zajedničko pismo Glavnom tajniku te svjetske organizacije. Ustvrdili su da „nema sumnje da u ovom trenutku Socijalistička Federativna Republika Jugoslavija više nije članica UN-a. U isto vrijeme jasno je da Savezna Republika Jugoslavija još nije članica“. Zamolili su Glavnoga tajnika da pruži pravno objašnjenje toga pitanja. 
Podtajnik i pravni savjetnik UN-a odgovorio je na to pitanje 29. rujna te godine. On je potpuno ignorirao navod iz preambule rezolucije 777 prema kojemu je SFRJ prestala postojati. Potvrdio je posljednju gore citiranu rečenicu iz rezolucije Opće skupštine 47/1, navodeći da je jedina praktična posljedica te rezolucije da Savezna Republika Jugoslavija (Srbija i Crna Gora) neće sudjelovati u radu Opće skupštine. Time je glavni pravni problem jednostavno zaobiđen jer se nisu imale u vidu retroaktivne posljedice primanja SRJ u članstvo UN-a koje se zbilo 1 . studenoga 2000. godine. ${ }^{25}$

Tim stvorenim stanjem članstvo SFRJ u UN-u nije nikada formalno okončano. Saveznoj Republici Jugoslaviji de facto je priznat položaj sličan Ruskoj Federaciji u odnosu na bivši SSSR. Od nje se čak tražilo da uplaćuje godišnje doprinose toj svjetskoj organizaciji. Ali time je postalo nejasno je li SFRJ temeljem kontinuiteta SRJ s njom i dalje postojala, ili je nestala. S tim će se teškoćama suočiti Međunarodni sud.

Kroz razdoblje do 1. studenoga 2000. kada je SRJ primljena u članstvo UNa, i time je navodno okončan njezin položaj sui generis, ponavljalo se pitanje je li ona bila ili nije bila članica UN-a i time stranka Statuta Međunarodnoga suda. Ako nije bila stranka Statuta, nije mogla biti ni tužiteljica niti tužena strana pred Međunarodnim sudom. Sljedeće je pitanje bilo, s obzirom na njezin naknadni položaj članice UN-a, je li ona u razdoblju koje je prethodilo bila i stranka Konvencije o genocidu iz 1948. godine. Ako to nije bio slučaj, ona pred tim Sudom nije mogla biti tužena za kršenje te Konvencije temeljem njezina članka IX.

Na gornji problem odnose se prva dva stavka članka 35. Statuta Suda u kojima je navedeno:

„1. Sud je otvoren državama strankama ovoga Statuta.

2. Uvjete pod kojima je on otvoren drugim državama propisuje, ne dirajući posebne odredbe ugovora koji su na snazi, Vijeće sigurnosti tako da ni u kojem slučaju iz toga ne proiziđe za stranke nikakva nejednakost pred Sudom.“

Stavak 1. odnosi se na sve države članice UN-a koje primanjem u tu svjetsku organizaciju postaju ipso facto stranke Statuta kao sastavnoga dijela Povelje UN-a. To izrijekom predviđa i članak 93(1). Povelje. To je bio položaj Bosne i Hercegovine, te Hrvatske, u vrijeme podizanja njihovih tužbi protiv SRJ. SRJ je pred Sudom taj položaj Bosne i Hercegovine bezuspješno pokušala osporiti.

Glede stavka 2, Vijeće sigurnosti usvojilo je još 15. listopada 1946. rezoluciju

25 Diplomati su možda vjerovali u to da će SRJ prekinuti svoju agresiju protiv Bosne i Hercegovine, a kao nagradu za to bili su joj spremni priznati položaj Ruske Federacije u odnosu na bivši SSSR. Do toga nije došlo i uslijedile su sve veće pretežito ekonomske sankcije protiv SRJ i područja Bosne i Hercegovine i Hrvatske pod srpskom okupacijom. Ali da se tako što i ostvarilo, SRJ ne bi imala povlašteni položaj u raspodjeli imovine, arhiva i dugova u odnosu na druge države sljednice bivše države. Ona bi samo naslijedila članstvo bivše države u međunarodnim organizacijama bez postupka primanja, te sva prava i obveze iz ugovora države prethodnice. Takav je i položaj Ruske Federacije u odnosu na SSSR. 
IX (1946.) koju od tada nije mijenjalo. Prema toj rezoluciji, države nečlanice UN-a mogu postati strankama Statuta temeljem jednostranih izjava kojima prihvaćaju nadležnost Suda u skladu s Poveljom i prema uvjetima iz Statuta i Pravilnika Suda. SRJ je vrludala u svome položaju koji je naknadno radikalno izmijenila, i to od pretenzije za kontinuitetom s državom prethodnicom koja je bila član osnivač $\mathrm{UN}-\mathrm{a}$, a što je podrazumijevalo njezin položaj predviđen u stavku 1, do tvrdnje da je sasvim nova država koja nije naslijedila nikakve dužnosti od države prethodnice (prema tzv. teoriji Clean slate). Na taj njezin izmijenjeni položaj odnosio bi se stavak 2. članka 35. Statuta. Kako smo naveli, i Sud je u različitim odlukama donosio kontradiktorne zaključke o njezinu položaju.

$*$

\section{BOSNA I HERCEGOVINA PROTIV SRJ (SRBIJE I CRNE GORE)}

\section{Uvod}

Nakon što je otpočeo niz krvavih sukoba na prostoru bivše SFRJ, države žrtve velikosrpskih napada poduzimale su različite mjere da im se suprotstave. Ogromne količine naoružanja i municije bivše „Jugoslovenske narodne armije“ protupravno je zadržao i prisvojio režim u Beogradu i njima je naoružao tzv. „Vojsku Republike Srpske“ u Bosni i Hercegovini i „Vojsku Srpske Krajine“ u Hrvatskoj. Žrtve tih napada bile su u neravnopravnom vojnom položaju i njih je napose pogađao embargo na uvoz oružja u Jugoslaviju propisan pravno obvezujućom rezolucijom Vijeća sigurnosti UN-a 713 od 25. rujna 1991.

U toj teškoj situaciji, nakon što je 22. svibnja 1992. postala članicom UN-a, a sljedećega 29. studenog notificirala sukcesiju Konvencije o genocidu, Bosna i Hercegovina je 20. ožujka 1993. podnijela tužbu Međunarodnom sudu protiv SRJ zbog kršenja te Konvencije iz 1948. godine. Istoga dana ona je od Suda zatražila izricanje privremenih mjera do konačne presude.

\section{Nalog o zahtjevu za privremenim mjerama od 8. travnja 1993.}

Sud se u tome svome Nalogu pozabavio sa svojom nadležnošću ratione personae, i to napose glede Savezne Republike Jugoslavije (Srbije i Crne Gore). Naveo je da taj problem ,nije lišen pravnih teškoća“,$^{26}$ ali je pitanje je li SRJ bila članica UN-a i kao takva stranka Statuta Suda takve naravi da ga Sud ne mora odmah i konačno riješiti u toj fazi postupka. ${ }^{27}$

26 I. C. J. Reports 1993, p. 14, para. 18.

27 Pri tome je Sud ipak naveo da bi se kompromisorna klauzula u mnogostranim konvencijama, „poput članka IX. Konvencije o genocidu“, mogla po njegovu mišljenju prima facie smatrati „posebnom odredbom“ u ugovoru u smislu članka 35(2). njegova Statuta. Ibid., p.14, para. 19. 
Ovim svojim zahtjevom za privremenim mjerama Bosna i Hercegovina je nastojala spriječiti, osim genocida, teško kršenje drugih ljudskih prava svojih građana; potom osigurati zabranu prijetnje i upotrebe sile protiv nje; zabranu uplitanja u njezine unutarnje poslove od strane SRJ i dr. Također je istaknula svoje pravo na samoobranu temeljem članka 51. Povelje UN-a, i stoga je zahtijevala da joj Sud prizna pravo da traži neodložnu pomoć od bilo koje druge države, i to unatoč nametnutom embargu od strane Vijeća sigurnosti na uvoz oružja u bivšu Jugoslaviju.

Sud je, međutim, u svome Nalogu od 8. travnja 1993. istaknuo da on ne može određivati mjere zaštite spornih prava koja su izvan domašaja Konvencije o genocidu. ${ }^{28}$ Ali držeći se tih okvira, on je propisao da Vlada SRJ mora neodložno poduzeti sve mjere u svojoj moći da spriječi počinjenje zločina genocida. Ona napose mora osigurati da vojne, paravojne ili neregularne oružane skupine, kao i svaka organizacija i osoba koja bi mogla biti pod njezinom kontrolom ili utjecajem, ne počini bilo koji čin genocida ili urotu da se počini genocid, neposredno i javno poticanje na genocid, ili suučesništvo u genocidu, bilo da su ti čini usmjereni protiv muslimanskoga stanovništva ili neke druge skupine u Bosni i Hercegovini. Na koncu je Sud pozvao Vlade u Beogradu i Sarajevu da ne poduzimaju nikakve korake koji bi mogli pogoršati postojeće stanje. ${ }^{29}$

$*$

\section{Nalog glede ponovljenoga zahtjeva za privremenim mjerama od 13. rujna 1993.}

Srpska se strana očito oglušila o sve te privremene mjere koje je Sud naložio i stoga je Vlada Bosne i Hercegovine 27. srpnja iste godine podnijela novi zahtjev za privremenim mjerama. Sud je otklonio prihvaćanje drugih dalekosežnih zabrana koje je Bosna i Hercegovina u tom svome drugom zahtjevu tražila, kao i zabrane koje je SRJ tražila u svojoj protutužbi. U odricanju bosanskih zahtjeva da, između ostaloga, zabrani plan podjele teritorija te države, da proglasi protupravnom aneksiju njezina područja i da potvrdi da Bosna i Hercegovina mora imati sredstva za prevenciju čina genocida i njezine podjele putem dobivanja vojne pomoći, Sud je ponovio da on u toj parnici ima prima facie nadležnost koja mu je povjerena jedino Konvencijom o genocidu. On nije ovlašten da se bavi širim zahtjevima. ${ }^{30}$ Sud je u tome Nalogu od 13. rujna 1993. u cijelosti potvrdio privremene mjere iz

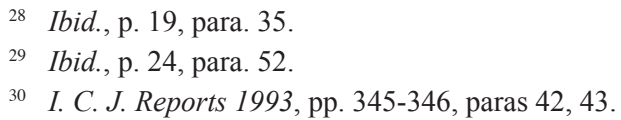


svoga prijašnjeg Naloga, ${ }^{31}$ a na protutužbu SRJ u kojoj se tvrdilo da su Srbi Bosne i Hercegovine žrtva genocida, nije se ni osvrnuo. ${ }^{32}$

$*$

\section{Presuda od 11. srpnja 1996. o prethodnim prigovorima}

U postupku o prethodnim prigovorima SRJ kao tužene države o nadležnosti Suda i dopustivosti tužbe, zastupnici Bosne i Hercegovine prizvali su različite „dopunske osnove nadležnosti“ koje bi Sudu omogućile „da se izjasni o nekim sredstvima kojima je Jugoslavija (SRJ) pribjegla pri počinjenju genocida za koji je optužena, napose njezino pribjegavanje agresivnom ratu u tijeku kojega je počinila teška kršenja Ženevskih konvencija iz 1949. i Dopunskih protokola I. i II. iz 1977.“ Ali je u toj svojoj presudi od 11. srpnja 1996. Sud odlučno odbacio to proširenje svoje nadležnosti na mala vrata. ${ }^{33}$ Ponovio je da ne može prihvatiti bilo koju od dopunskih osnova nadležnosti na koje se pozivao tužitelj i da je on jedino nadležan da odlučuje u parnici na temelju članka IX. Konvencije o genocidu. ${ }^{34}$

Ovdje ćemo iznijeti neke druge, ali ne sve stavove Međunarodnoga suda iz ove presude. Tužena je strana uložila mnogo napora i financijskih sredstava da izbjegne da se Međunarodni sud izjasni o navodima tužbe Bosne i Hercegovine. Ona je podnijela ukupno sedam prigovora na nadležnost Suda u toj parnici, kao i dva prigovora o nedopustivosti tužbe. Njima je pokušala dokazati da navodni građanski rat u Bosni i Hercegovini isključuje postojanje međunarodnoga spora, da SRJ nije bila strana u tome sukobu, da je Bosna i Hercegovina, proglašujući svoju neovisnost, navodno flagrantno prekršila svoje obveze iz načela samoodređenja naroda, i sl.

U četvrtom prigovoru SRJ je zanijekala i samo postojanje Bosne i Hercegovine kao države, unatoč tome što je ona, uz Hrvatsku i Sloveniju, u međunarodnoj zajednici bila općenito priznata, a 22. svibnja 1992. postala je i članicom UN-a. Taj je prigovor glasio:

„Budući da je tzv. Republika Bosna i Hercegovina priznata u uvjetima suprotnima pravilima međunarodnoga prava, (sic!) ${ }^{35}$ da ona nije nikada ustanovljena na području koje smatra svojim i u obliku u kojemu pretendira da

31 Ibid., p. 349, para. 59.

32 U dispozitivu presude o meritumu toga spora od 26. veljače 2007. u točki (7) konstatirano je da je „Srbija prekršila svoju obvezu da izvrši privremene mjere koje je Sud naložio 8. travnja i 13. rujna 1993. u ovoj parnici jer nije poduzela sve mjere koje su bile u njezinoj moći da spriječi genocid počinjen u Srebrenici u srpnju 1995.“, Cf., I. C. J. Reports 2007, p. 238, para. 471(7). Ali osim te konstatacije, Sud nije propisao nikakve mjere zbog kršenja te obveze.

33 I. C. J. Reports 1996, pp. 617-618, para. 35.

34 Ibid., p. 621, para. 41.

35 Priznanje ili odbijanje priznanja neke nove države politički je čin na koji se nadovezuju pravne posljedice. Država koja odbije priznati drugu državu time ne krši nikakvo pravilo međunarodnoga prava, te stoga niti čin priznanja ne može sam po sebi biti suprotan pravilima toga prava. 
postoji nakon nezakonite deklaracije o neovisnosti, i budući da danas postoje četiri države na području bivše jugoslavenske Republike Bosne i Hercegovine, tzv. Republika Bosna i Hercegovina nije stranka konvencije iz 1948. godine o sprečavanju i kažnjavanju zločina genocida, i stoga - Sud nije nadležan u ovoj parnici. “36

Tom tvrdnjom SRJ je neizravno sam posvjedočio da je vodio agresivni rat u toj državi članici UN-a i da je vjerovao da je svojim osvajanjima njezina područja nju kao državu uništio. Ali je potpisivanjem sporazuma Dayton-Pariz koncem 1995., od toga prigovora odustao jer su se njime te dvije države uzajamno priznale u postojećim granicama.

Ipak je ostao prigovor u kojemu je tužena strana tvrdila da je tužba nedopustiva s obzirom da g. Alija Izetbegović nije bio ovlašten da je podnese Sudu, i da on u to vrijeme nije čak ni zakonito djelovao. On tada nije bio predsjednik Republike nego samo predsjednik Predsjedništva Bosne i Hercegovine. Sud je taj prigovor s uvjerljivim razlozima odbio, navodeći najprije da on nije dužan ispitivati propise unutarnjega prava bilo u prilog ili protiv toga prigovora:

„Prema međunarodnom pravu nema sumnje da se pretpostavlja da je svaki glavar države sposoban da djeluje u ime (svoje) države u međunarodnim odnosima (vidi npr. Bečku konvenciju o pravu ugovora, članak 7, stavak 2(a)). Kao što je Sud ustanovio u Nalogu od 8. travnja 1993., (I. C. J. Reports, 1993., p. 11, para. 13), u trenutku podnošenja tužbe g. Izetbegović bio je priznat, napose od Ujedinjenih nacija, kao glavar države Bosne i Hercegovine. Čak što više, njegov položaj glavara države i dalje se priznavao u mnogim međunarodnim tijelima i neki međunarodni sporazumi - uključujući sporazume Dayton-Pariz - nose njegov potpis. “37

Kao posljedica srpske agresije i teritorijalnih osvajanja u Bosni i Hercegovini, Vlada u Sarajevu imala je kontrolu nad manje od polovice svoga područja. Ali se i inače ponekad događalo u nekim drugim zemljama, poput Libanona, Kambodže, Albanije, Liberije, i danas Somalije i Libije, da uslijed unutarnjih sukoba različitih frakcija privremeno prestane djelovati svaka središnja vlast. Ipak, ta svjetska organizacija ne briše zbog toga te države iz svoga članstva. Organi UN-a i dalje priznaju kao legitimnu posljednju vladu i njezine predstavnike, $\mathrm{i}$ to sve dok se u toj državi stanje ne konsolidira i dok se ne održe izbori za novu vlast. Srbija, ali i neki krugovi u Hrvatskoj, smatrali su da je Bosna i Hercegovina naprosto prestala postojati, ili da se ono što je tada od nje ostalo ubuduće neće moći održati. To stajalište otpočetka je bilo krivo i nanijelo je ogromnu štetu položaju tih zemalja u međunarodnoj zajednici.

Za razliku od svoga Naloga o privremenim mjerama od 8. travnja 1993., Sud u ovoj presudi nije uopće raspravljao o položaju SRJ u Organizaciji ujedinjenih nacija i o pitanju je li ona tada bila stranka Statuta Suda. Bilo mu je dovoljno

\footnotetext{
36 Vidi I. C. J. Reports 1996., pp. 604-605, para. 14.

${ }^{37}$ Ibid., p. 622, para. 44.
} 
da ustanovi da je temeljem Deklaracije od 27. travnja 1992. SRJ bila stranka Konvencije o genocidu ,i da to nitko nije osporavao“. ${ }^{38}$

U presudi koju je izrekao 11. srpnja 1996. Sud je znatnom većinom glasova odbacio sve prethodne prigovore SRJ i proglasio se nadležnim da odlučuje o navodima tužbe Bosne i Hercegovine.

\section{Presuda od 3. veljače 2003. o Zahtjevu za revizijom}

U rujnu 2000. Slobodan Milošević je bio poražen na predsjedničkim izborima i, kao rezultat demonstracija u Beogradu, bio je lišen sve vlasti u SRJ. Nova vlada Zorana Đinđića nastojala je poput prijašnjih vlada okončati postupak pred Međunarodnim sudom, ali je $\mathrm{u}$ isto vrijeme bila spremna na suradnju $\mathrm{s}$ Međunarodnim kaznenim tribunalom za bivšu Jugoslaviju. Sljedeće godine Milošević je bio u Beogradu uhićen i potom izručen Tribunalu u Haagu.

Nova se Vlada odrekla zahtjeva za kontinuitetom s bivšom SFRJ nakon čega je bilo moguće postići Sporazum o pitanjima sukcesije s drugim državama sljednicama u 2001. godini u Beču.

S političkoga aspekta razumljivo je da je nova vlada u Beogradu pokušavala izbjeći odgovornost SRJ i Srbije za međunarodne zločine koje je počinila prijašnja vlast, i to sve dok je bila spremna da osumnjičenike izloži kaznenom progonu u njihovom osobnom svojstvu. Ali Bosna i Hercegovina nije bila voljna povući svoju tužbu pred Haškim sudom. Iz aspekta žrtava počinjenih zločina to je također bilo razumljivo.

Dana 24. travnja 2001. SRJ je pokrenula postupak pred Međunarodnim sudom za reviziju njegove presude iz 1996. o prethodnim prigovorima. Taj se zahtjev zasnivao na članku 61. Statuta Suda. ${ }^{39}$ SRJ je ustvrdila da je njezino primanje u članstvo UN-a 1. studenoga 2000. „nova činjenica“ i odlučujući čimbenik glede pitanja nadležnosti Suda ration personae. Ona je ustvrdila da je nakon njezina primanja $u$ to članstvo nesporna činjenica da SRJ nije produljila personalitet SFRJ, da prije toga datuma nije bila članica UN-a i da nije bila stranka Statuta Suda, niti stranka Konvencije o genocidu iz 1948.

Kada je kao nova država notificirala svoj pristup toj Konvenciji 6. ožujka 2001., SRJ je dala dalekosežnu rezervu Glavnom tajniku UN-a kao njezinu depozitaru. U njoj je navela da se ne smatra obveznom njezinim člankom IX. prije nego što dade svoj pristanak glede bilo kojega spora. Zanimljivo je da se na tu svoju rezervu SRJ nije pozivala u tri spora koji su već bili u tijeku.

38 Ibid., p. 610, para. 17.

39 Stavak 1. članka 61. glasi: „Revizija presude može se zahtijevati samo na temelju otkrića neke činjenice takve prirode da bi odlučujuće djelovala, a koja je prije izricanja presude bila nepoznata Sudu i stranci koja traži reviziju, a da pri tom to neznanje ona nije skrivila." 
U presudi izrečenoj 3. veljače 2003. zahtjev SRJ za revizijom proglašen je nedopustivim. Sud je naglasio da nije ustanovljeno da je zahtjev SRJ za članstvom u UN-u bio otkriće „nove činjenice“ koja Sudu nije bila poznata u 1996. Stoga, pošto jedan od kumulativnih uvjeta za revizijom te presude nije bio zadovoljen, Sud nije smatrao potrebnim upuštati se u ispitivanje drugih uvjeta iz članka 61 .

$\mathrm{U}$ toj presudi detaljno su bili u nizu opisani instrumenti, kako same SRJ, tako i tijela UN-a glede njezina položaja u UN-u i pitanja je li ona bila stranka Konvencije o genocidu iz 1948. Ali ta presuda stvarno nije dirala u stanje prije 1. studenoga 2000. koje je ostalo krajnje nejasno. Prije smo naveli da je Sud u prvom Nalogu o privremenim mjerama iz travnja 1993. naveo da je pitanje njezina članstva u UN-u i položaja stranke njegova Statuta takve naravi da se u toj fazi ne mora konačno riješiti. U presudi o prethodnim prigovorima iz 1996. on je sebi dozvolio da uopće ne razmatra pitanje je li SRJ tada bila stranka Statuta Suda ili ne. Dovoljna mu je bila Deklaracija od 27. travnja 1992. za zaključak da je ona bila stranka Konvencije o genocidu, što tada nitko nije dovodio u pitanje.

S obzirom na to da osim odbacivanja zahtjeva za reviziju prethodne presude iz 1996. Sud u ovoj presudi nije ni o čemu odlučio, to znači da je i u njoj implicitno priznao kontinuitet SRJ s bivšom SFRJ.

Nedugo nakon izricanja te presude, 12. ožujka 2003. neki bivši pripadnici Miloševićeve policije ubili su Zorana Đinđića u atentatu. Nove vlasti bile su u početku manje raspoložene za suradnju s međunarodnom zajednicom u kažnjavanju zločinaca u Hrvatskoj, Bosni i Hercegovini i na Kosovu, i to je privremeno oslabilo međunarodni položaj Srbije. Ipak je Srbija uz pomak vremena izručila Tribunalu Radovana Karadžića, Ratka Mladića i Gorana Hadžića.

$*$

\section{Presuda od 26. veljače 2007. o meritumu}

I u konačnoj presudi o meritumu toga dugotrajnog spora iz 2007. Sud je potvrdio svoj stav iz prijašnjih odluka o ograničenjima u svojoj nadležnosti, i to sljedećim izričajem:

„Nadležnost Suda u ovoj parnici zasnovana je jedino na članku IX. Konvencije. Sve druge osnove nadležnosti na koje se tužitelj pozvao odbačene su u presudi iz 1996. o nadležnosti (I. C. J. Reports 1996. (II), pp. 617-621, paras 35-41)... On nema ovlasti da odlučuje o navodnim kršenjima drugih obveza prema međunarodnom pravu koje se ne sastoje u genocidu, napose ne o onima glede zaštite ljudskih prava u oružanom sukobu. To je tako čak kada se radi o navodnim kršenjima obveza iz imperativnih normi, ili obveza koje štite temeljne humanitarne vrijednosti s domašajem erga omnes. " ${ }^{\circ 0}$ 
Ali Sud je s time u vezi objasnio...

bitnu razliku između postojanja i obvezujuće snage dužnosti koje proizlaze iz međunarodnoga prava i postojanja činjenice da ne postoji (neki) sud ili tribunal s nadležnošću da rješava sporove o poštovanju tih obveza. Činjenica da takav sud ili tribunal ne postoji ne znači da ne postoje obveze. One zadržavaju svoju valjanost i pravnu snagu. Od država se zahtijeva da izvršavaju svoje obveze prema međunarodnom pravu, uključujući napose međunarodno humanitarno pravo, i one ostaju odgovorne za akte suprotne međunarodnom pravu koji su njima pripisivi." "41

Gornje znači da agresija, zločini protiv čovječnosti i ratni zločini nisu u međunarodnom pravu manje zabranjeni zbog toga što nisu pokriveni člankom IX. Konvencije o genocidu, ili što ne postoji slična konvencija koja bi predviđala jednostranu sudsku tužbu jedne države stranke protiv druge u slučaju njihova kršenja.

I zaista, već nakon presude izrečene u 1996., nije bilo nikakvoga uporišta da će se, osim za genocid, Sud htjeti izjašnjavati o odgovornosti tužene države za agresiju i za počinjenje drugih međunarodnih zločina, uključujući tu i čine etničkoga čišćenja koji nemaju obilježja genocida. Svakomu tko prati praksu toga Suda i njegova prethodnika Stalnoga suda međunarodne pravde još od 1922. godine, savršeno je jasno da on nikada neće pristati na proširenje svoje nadležnosti onako kako su zastupnici tužbe Bosne i Hercegovine to predlagali. Protiv toga stava Suda ne mogu se iznaći uvjerljivi pravni razlozi kojima bi se on mogao osporiti.

Odgovorni političari i pravnici koji su produljivali postojeće ili pokretali nove sporove temeljem članka IX. Konvencije o genocidu time su gurali svoje države u nove troškove jalovoga parničenja. Pri tome nije bilo nikakvih izgleda da će se od tužene države tim putem naplatiti neka naknada za međunarodne zločine koji su stvarno bili počinjeni, ali koji nisu u nadležnosti Međunarodnoga suda.

Konačna presuda o genocidu po tužbi Bosne i Hercegovine koju je Međunarodni sud izrekao 26. veljače 2007. godine zasnivala se na međunarodnim instrumentima koje smo naprijed naveli. Sud se čvrsto držao svoje presude o prethodnim pitanjima iz 1996. godine i ispitao je sve navode u tužbi Bosne i Hercegovine. ${ }^{42} \mathrm{U}$ tome pogledu on se pozivao na načelo res judicata. ${ }^{43}$

Sud je procjenjivao dolus specialis prema propisima međunarodnoga kaznenog prava, i tu se upirao na nalaze iz presuda Krstiću i Blagojeviću Međunarodnoga kaznenog tribunala za bivšu Jugoslaviju. A odgovornost SRJ koji je Bosna i Hercegovina tužila za zločine genocida počinjene na svome području Sud je procjenjivao temeljem pravila o pripisivosti iz Nacrta pravila o odgovornosti

$41 \quad$ Ibid., p. 104, para. 148.

42 Reports 2007., pp. 101-102, para. 140.

43 Ibid., pp. 89-101, paras 114-139. 
država Komisije za međunarodno pravo.Ova prva presuda o meritumu po tužbi za genocid, koja obuhvaća 200 stranica teksta, a zajedno s odvojenim i posebnim mišljenjima sudaca ukupno 580 stranica, dala je odgovor na mnoga pitanja koja su prije toga bila predmetom sporova između država i u znanosti.

Pitanje je bilo odnosa toga glavnog sudskog organa UN-a i Međunarodnoga kaznenog tribunala za bivšu Jugoslaviju koji je ustanovljen rezolucijom Vijeća sigurnosti. Naime, u ranoj fazi svojih djelatnosti Tribunal se upuštao u ocjenu odgovornosti država prema općem međunarodnom pravu, za što nije mogao biti ovlašten bez pristanka svih strana spora u pitanju.

U okviru svojih normalnih djelatnosti, taj Kazneni tribunal ne može izbjeći pitanje primjenjivosti članka 2. njegova Statuta, tj. teških kršenja Ženevskih konvencijaiz 1949. S obzirom na to da je taj članak neprimjenjiv u nemeđunarodnim tj. unutarnjim sukobima, potrebno je utvrditi je li na području odgovornosti nekoga optuženika, napose vojnoga zapovjednika, postojao ili nije istinski međunarodni sukob. Ali bi se razmatranje Tribunala na tome trebalo zaustaviti. U samome Statutu, propustom njegovih sastavljača, manjkavo su sročena pravila primjenjiva na unutarnje sukobe.

Tu je prazninu u svome Statutu iskoristio Tribunal da se izjašnjava o brojnim pitanjima općega međunarodnog prava, uključujući i o odgovornosti država, za što nije ni nadležan, ni po svojoj naravi podesan. To napose stoga što je iz njegove nadležnosti isključen kazneni progon počinitelja zločina agresije.

Tako je Tribunal „uletio“ u pitanja odgovornosti susjednih država za djelatnosti različitih paravojnih formacija pod njihovom navodnom kontrolom, i to napose na području Bosne i Hercegovine. Članak 8. Pravilâ o odgovornosti država Komisije za međunarodno pravo predviđa odredbu glede ,ponašanja pod nadzorom ili kontrolom države“ u sljedećem sadržaju: „Ponašanje neke osobe ili skupine osoba smatra se prema međunarodnom pravu djelom države ako ta osoba ili ta skupina osoba, usvajajući to ponašanje, stvarno djeluje po nalozima ili pod nadzorom ili kontrolom te države." Tu se može napose raditi o osobama regrutiranima u pomoćne oružane snage ili o ,dragovoljcima“ koji djeluju u drugoj državi u sklopu oružanih snaga države u pitanju.

U prije izrečenoj presudi Nikaragva iz 1986. godine Međunarodni je sud utvrdio odgovornost Sjedinjenih Država zbog toga što je njihova tajna služba CIA sudjelovala u ,pripremanju, upravljanju i u podršci“ kontrasima u Nikaragvi. Ali je Sud odbio proglasiti Sjedinjene Države odgovornima i za pojedinačne protupravne djelatnosti tih kontrasa u nedostatku dokaza o „efektivnoj kontroli“ nad njihovim vojnim i paravojnim operacijama. ${ }^{44}$

Tribunal za bivšu Jugoslaviju nije se zadovoljio tim kriterijem ,efektivne kontrole“",tvrdeći da je on u neskladu s međunarodnom sudskom praksom i praksom država (sic!). U presudi Žalbenoga vijeća Tadić iz 1999., i u prvostupanjskoj presudi Blaškić iz 2000., on je snizio taj prag glede dokazivanja odgovornosti

$44 \quad$ Cf., I. C. J. Reports 1986., p. 51, para. 86; pp. 62 i 65-65, paras. 109. i 115. 
država, uvodeći tzv. „test cjelovite kontrole“ (test of overall control). Prema tome testu, opskrba, obuka i financiranje Vojske Republike Srpske i Hrvatskoga vijeća obrane u Bosni i Hercegovini podrazumijevaju ulogu SRJ, odnosno Hrvatske, u organiziranju, koordiniranju i planiranju vojnih akcija tih skupina čak i u nedostatku specifičnih instrukcija tih država glede poduzetih vojnih operacija. Stoga je Tribunal te skupine i njihove članove olako proglasio de facto organima tih država koji navodno angažiraju odgovornost SRJ, odnosno Hrvatske i čine te sukobe „međunarodnima“.

$\mathrm{Na}$ tu ,zakonodavnu djelatnost“ odlučno je reagirao Međunarodni sud u ovoj presudi iz 2007. godine, naglašujući:

„Sud nalazi da on nije u mogućnosti podržati (to) gledište Vijeća (Tribunala). Najprije, Sud primjećuje da Međunarodni kazneni tribunal za bivšu Jugoslaviju nije u slučaju Tadić bio pozvan, niti je općenito pozvan, da odlučuje o pitanjima odgovornosti države, s obzirom na to da je njegova nadležnost kaznena i proteže se samo na (fizičke) osobe. Dakle, u toj svojoj presudi Tribunal je odlučivao o pitanju koje nije nužno za vršenje njegovih nadležnosti... Sud pridaje najveći značaj činjeničnim i pravnim nalazima Tribunala za bivšu Jugoslaviju i odlučivanju o kaznenoj odgovornosti optuženika pred njime... Ali situacija nije ista glede stavova koje je usvojio taj Tribunal o pitanjima općega međunarodnog prava koja ne potpadaju pod njegovu specifičnu nadležnost, a povrh toga njihovo rješavanje nije uvijek nužno za odlučivanje o kaznenim predmetima pred njim. “45

Sud je uz to ustanovio veliki nedostatak testa cjelovite kontrole jer on proširuje domašaj odgovornosti države preko temeljnih načela koja uređuju taj dio međunarodnoga prava. Država je odgovorna samo za svoje vlastito ponašanje, tj. za ponašanje osoba koje po nekoj osnovi djeluju u njezino ime. Ukoliko je država odgovorna i za čine osoba ili skupina osoba koje nisu njezini organi, to može biti slučaj ako im je izdavala naredbe da izvrše protupravna djela, ili je glede tih djela imala efektivnu kontrolu. ${ }^{46}$

Držeći se gornje distinkcije, Međunarodni se sud drukčije ponašao glede činjenica koje je utvrdio Tribunal, kao i namjere počinitelja (dolus specialis). Tu oba ta sudišta primjenjuju ista pravila iz Konvencije o genocidu iz 1948. godine. Nakon prikaza argumenata stranaka o važnosti pojedinih dokumenata toga Tribunala $\mathrm{i}$ analize različitih faza njegova postupka, Sud je zaključio da on u načelu treba pridati visoko uvjerljiv značaj nalazima Tribunala o činjenicama u prvostupanjskom postupku, osim, naravno, ako su oni opozvani u prizivu. Iz istih razloga on treba pridati primjerenu težinu svakoj ocjeni Tribunala zasnovanoj na utvrđenim činjenicama koja se odnosi npr. na postojanje neophodne namjere. ${ }^{47}$

U tijeku postupka u ovoj parnici zastupnici Bosne i Hercegovine nisu se posebno upuštali u dokazivanje genocidne namjere (dolus specialis) počinitelja

\footnotetext{
45 I. C. J. Reports 2007., para. 403.

46 Ibid., p. 210, para. 406.

47 Ibid., p. 134, para. 223.
} 
svakoga od zločina čije su izvršenje (actus reus) inače uspjeli dokazati. Umjesto toga, oni su pokušali dokazati izvjestan model ponašanja srpskih vlasti u Bosni i Hercegovini, ali i na području Savezne Republike Jugoslavije, kao navodnu genocidnu politiku usmjerenu također protiv pripadnika manjina u toj zemlji. Očekivali su da će iz te zajedničke politike sam Sud izvesti genocidnu namjeru počinitelja. Ali Sud nije prihvatio ni taj skupni način dokazivanja dolus specialis.

„Dolus specialis, specifična namjera da se u cijelosti ili djelomično uništi skupina u pitanju, mora se uvjerljivo dokazati upućivanjem na posebne okolnosti, osim ukoliko se može uvjerljivo dokazati postojanje općega plana u tu svrhu; a da bi se neki model ponašanja prihvatio kao dokaz postojanja toga plana, on mora biti takav da ukazuje na tu namjeru. “48

Zastupnici Bosne i Hercegovine i kasnije Hrvatske bili su napose mišljenja da je dovoljno dokazati sprovedeno etničko čišćenje nekoga prostora i njegove nehumane posljedice i da se time dokazao zločin genocida. Tu je Sud opet usvojio krajnje restriktivno stajalište kojega se držao i u parnici po tužbi Hrvatske.

U vezi s time Sud smatra da „etničko čišćenje“ može činiti oblik genocida u smislu Konvencije iz 1948. jedino ukoliko odgovara nekoj od kategorija zabranjenih djela u njezinu članku II, ili proizlazi iz nje. Ni namjera u obliku neke politike da se neko područje učini „etnički homogenim“, a ni operacije koje se mogu poduzeti u ostvarenju takve politike, ne mogu kao takve biti nazvane genocidom. To, međutim, ne znači da čini nazvani „etničkim čišćenjem“ ne mogu nikada predstavljati genocid, ukoliko su takvi da se mogu okarakterizirati kao npr. „,namjerno podvrgavanje skupine takvim uvjetima života koji bi trebali dovesti do njezinog potpunog ili djelomičnog uništenja“ u kršenju članka II. stavka (c) Konvencije, pod rezervom da se takva akcija provela s neophodnom specifičnom namjerom (dolus specialis), tj. s namjerom uništenja skupine, a ne samo njezina protjerivanja s nekoga područja. ${ }^{49}$

Sud se u toj svojoj presudi u cijelosti oslonio na dokaze o postojanju dolus specialis iz presuda Međunarodnoga kaznenog tribunala za bivšu Jugoslaviju protiv oficira Vojske Republike Srpske Krstića i Blagojevića. Krstić je bio pravomoćno osuđen za pomaganje i podupiranje genocida u Srebrenici s genocidnom namjerom. ${ }^{50}$

48 Ibid., pp. 196-197, para. 373.

49 Reports 2007., p. 123, para. 190.

50 S Blagojevićem je bio ponešto drukčiji slučaj. Žalbeno vijeće Tribunala izreklo je u njegovu slučaju konačnu presudu 9. svibnja 2007., dakle nakon izricanja presude Međunarodnoga suda. U doba srebreničkoga masakra on je bio na nižem položaju komandanta Bratunačke brigade i navodno nije znao za masovna ubojstva izvan područja svoje odgovornosti. Stoga je Žalbeno vijeće ukinulo dio presude Prvostupanjskoga vijeća o njegovu sudioništvu (complicity, supočiniteljstvu) u genocidu, jer njegova genocidna namjera nije bila izvan razborite sumnje utvrđena. Ali ga Zalbeno vijeće nije oslobodilo krivnje glede pomaganja i podupiranja (aiding and abetting) samoga toga zločina jer su Drugi bataljun i Treća artiljerijska grupa pod njegovim zapovjedništvom imali udjela u napadima na civile na putu u Potočare, u patroliranju područja u i oko Potočara 12. i 13. srpnja 1995., i u pomaganju transfera civila. Dakle actus reus se u ovom slučaju sastojao u genocidu i Žalbeno vijeće nije moglo prekvalificirati pomaganje i podupiranje njegova izvršenja u neki drugi, blaži međunarodni zločin. Da je to i moglo učiniti, čitav ovaj slučaj izgubio bi autoritet presedana za 
Zaključak Suda, učvršćen presudama prvostupanjskih vijeća u slučajevima Krstić i Blagojević, bio je da je neophodna namjera ustanovljena tek nakon promjene vojnoga cilja (od „ograničenja enklave na urbanu zonu“ na zauzeće grada Srebrenice i čitave enklave), te zauzimanjem Srebrenice 12. ili 13. srpnja (1995). „Sud nema razloga da odstupi od zaključka Tribunala prema kojemu je potrebna specifična namjera (dolus specialis) ustanovljena tada i samo tada." ${ }^{\text {"51 }}$ Ali se dalje navodi da gornja odluka nije bila priopćena vlastima u Beogradu. Budući da je glavni optuženik za taj strašni zločin general Ratko Mladić tada bio u bijegu, da te presude nisu bile prije izrečene, Međunarodni sud ne bi bio u stanju ustanoviti genocid čak ni u Srebrenici.

Iz toga aspekta proizlazi da se odgovornost države i kaznena odgovornost pojedinaca naredbodavaca i izvršitelja ne može mehanički razdvajati, i to napose ne kada je u pitanju genocid.

*

Presuda iz 2007. godine otkrila je slabost postupka pred Međunarodnim sudom za koju njegovi suci nisu odgovorni. Za razliku od kaznenih tribunala koji u svojem sastavu imaju tužiteljstva koja utvrđuju počinjenje zločina i moguću genocidnu namjeru počinitelja po službenoj dužnosti, takvo tijelo ne postoji u sklopu Međunarodnoga suda koji presuđuje sporove između suverenih država. U parnicama pred Međunarodnim sudom države tužiteljice dužne su same prikupiti uvjerljive dokaze o počinjenim zločinima i o genocidnoj namjeri tužene države. Ali niti one, a ni Međunarodni sud u Haagu, ne mogu prikupljati takve dokaze na području tužene države bez njezina pristanka. Ukoliko ih država u pitanju ne uspije prikupiti, bolje joj je da ne podnosi tužbu Sudu temeljem članka IX.

Gornje je imalo za posljedicu da je Sud u Haagu utvrdio zločin genocida samo u Srebrenici u srpnju 1995., ali nigdje drugdje u Bosni i Hercegovini, niti na području tadašnje Savezne Republike Jugoslavije, uključujući i Kosovo. Kako smo naveli, može se nagađati da Međunarodni sud ne bi mogao utvrditi ni genocid u Srebrenici da genocidnu namjeru nije prije toga utvrdio Kazneni tribunal za bivšu Jugoslaviju u presudama Krstić i Blagojević. Dakle, sama Bosna i Hercegovina nije bila u stanju dokazati genocid na temelju dokaza koje je ona mogla prikupiti.

Ali je presuda iz 2007. ipak značajna glede utvrđivanja preostalih zločina počinjenih sa srpske strane na glavnim područjima Bosne i Hercegovine i u različitim zatočeničkim logorima, i to sve prema navodima tužbe. Zaključci Suda o počinjenim zločinima zasnovani su na konačnim presudama Međunarodnoga

\footnotetext{
Međunarodni sud koji je svoju presudu već bio izrekao. U toj situaciji tako je došlo do neobičnoga rješenja prema kojemu za pomaganje i podupiranje genocida nije neophodan dolus specialis. Po toj osnovi Blagojeviću je više simbolički umanjena kazna zatvora sa 18 na 15 godina. Ipak sam opis i kvalifikacija događaja važnih za Međunarodni sud nisu s tom najnovijom presudom Žalbenoga vijeća uopće dovedeni u pitanje.

${ }^{51}$ Ibid., pp. 165-166, para. 295.
} 
kaznenog tribunala za bivšu Jugoslaviju, na izvješćima Komisije Mazowiecki, izvješćima Glavnoga tajnika UN-a, i na drugim nepristranim izvorima. Činjenice koje je Sud u toj presudi utvrdio zaista su užasne i ne mogu se pravdati nikakvim političkim ciljevima.

U presudi se tako izrijekom spominju: područje Sarajeva; dolina Drine sa Zvornikom i logorima Sušica, KPD Foča i Batković; potom Prijedor s Kozarcem i Hambarinama, te logori Omarska, Keraterm i Trnopolje; Banja Luka s logorom Manjača; Brčko s logorom Luka; te Srebrenica. Tako se za logor u Omarskoj navodi ocjena Komisije Mazowieckoga da se, prema dostupnim podacima, nije radilo ni o čemu drugom nego o logoru smrti. Slično je bilo i u logoru Keraterm.

Ipak, odluke Suda bile su mnogo skromnije od očekivanih. Glede zabranjenih djela koja čine actus reus toga zločina propisanoga u članku II. Konvencije o genocidu - i to: (a) ubojstava pripadnika skupine, (b) nanošenja teških tjelesnih i duševnih povreda pripadnicima skupine, i (c) namjernoga nametanja skupini životnih uvjeta kojima je cilj njezino potpuno ili djelomično uništenje - Sud je ustanovio da je materijalni element tih djela dokazan. Ali prema mišljenju Suda, tužitelj nije dokazao genocidnu namjeru počinitelja u izvršenju svih tih mnogobrojnih zločina. ${ }^{52}$

Glede preostalih djela iz članka II. Konvencije, Sud je ustanovio kako mu dokazi koji su mu predočeni ne omogućuju da zaključi da su snage bosanskih Srba počinile: (d) „nametanje mjera s namjerom sprečavanja porođaja u okviru skupine“; i (e) „prisilno premještanje djece iz skupine u neku drugu skupinu“. ${ }^{53}$

U toj presudi Haškoga suda navodi se da za počinjeni zločin genocida u Srebrenici odgovornost snosi Vojska Republike Srpske sa svojim zapovjedništvom. ${ }^{54} \mathrm{Na}$ jednom se mjestu u njoj konstatira da Republika srpskoga naroda u Bosni i Hercegovini (u 1992.) i potom Republika Srpska, nije ni tada ni kasnije bila međunarodno priznata kao država, ali je uživala izvjesnu de facto neovisnost. Na drugom se mjestu još navodi da je ona imala de facto kontrolu nad značajnim područjem i da je uživala lojalnost velikoga broja bosanskih Srba. ${ }^{55}$

Bosna i Hercegovina je za kršenje Konvencije o genocidu iz 1948. u toj parnici tužila Saveznu Republiku Jugoslaviju (Srbiju i Crnu Goru). Ona nije mogla Sudu tužiti tu međunarodno nepriznatu tvorevinu, koja uz to danas čini jedan od dvaju entiteta same Bosne i Hercegovine.

Tako je samome Sudu bilo pripalo da u toj presudi odlučuje o pripisivosti genocida u Srebrenici tadašnjoj Saveznoj Republici Jugoslaviji. Radilo se o pitanju je li SRJ prekršila neku od svojih obveza iz članka III. Konvencije o genocidu kao njezina stranka, i to: za sam genocid; za njegovo planiranje; za neposredno i javno poticanje na genocid; za pokušaj genocida; te za suučesništvo u genocidu.

\footnotetext{
52 Reports 2007., p. 155, para. 277; p. 175, para. 319.

53 Ibid., p. 192, para. 361; p. 193, para. 367.

54 Ibid., pp. 198-219, paras 377-424.

55 Ibid., pp. 138, 139, paras 233, 235.
} 
U presudi je bilo zaključeno da nije dokazano da je Vojska Jugoslavije sudjelovala u srebreničkom zločinu, ili da je političko vodstvo SRJ imalo udjela u njegovu pripremanju, planiranju ili izvršenju na drugi način. ${ }^{56}$ Navodi se da ima mnogo dokaza o neposrednom ili posrednom sudjelovanju oficira Vojske Jugoslavije, zajedno s Vojskom Republike Srpske, u vojnim operacijama u Bosni i Hercegovini, ali prije srebreničkih događaja. Međutim ni Republika Srpska, ni njezina Vojska nisu bile organi SRJ. ${ }^{57}$

U toj svjetlosti ipak se ne čini primjerenim kategoričan zaključak u točki (2) dispozitiva presude, prema kojemu Sud nalazi „da Srbija nije počinila genocid putem svojih organa ili osoba, čiji akti angažiraju njezinu odgovornost prema običajnom međunarodnom pravu, u kršenju svojih obveza iz Konvencije o sprečavanju i kažnjavanju zločina genocida“. Preciziniji bi bio nalaz da se to može zaključiti jedino na temelju dokumenata podnesenih Sudu, jer novi dokazi mogu ukazati na drukčije.

Ista se primjedba odnosi na točku (3) dispozitiva presude prema kojemu se Srbija navodno nije urotila u počinjenju genocida, niti poticala na njega; te na točku (4) da nije bila njegovim suučesnikom u kršenju svojih obveza iz Konvencije. Novi dokazi o umiješanosti Srbije u masakr u Srebrenici omogućili bi Bosni i Hercegovini da podnese Sudu zahtjev za reviziju presude iz 2007., u skladu s restriktivnim pravilima iz članka 61. njegova Statuta.

S druge strane, nalazimo važnim i opravdanim zaključak Suda iz točke (5) dispozitiva presude prema kojemu je Srbija prekršila svoju obvezu iz Konvencije iz 1948. da spriječi zločin u Srebrenici. U presudi je bilo navedeno kako tužena strana nije pokazala da je poduzela bilo kakvu inicijativu da spriječi ono što se dogodilo, ili bilo kakvu akciju da počinitelje odvrati od okrutnosti.

Ali najslabija strana čitave ove presude leži po mišljenju ovoga pisca u zaključku u točki (9) njezina dispozitiva, da u pogledu kršenja obveze Srbije na prevenciju zločina, nalazi samoga Suda u tome dispozitivu predstavljaju primjerenu zadovoljštinu ,i da u ovomu slučaju nalog za plaćanjem financijske kompenzacije ne bi bio primjeren“. ${ }^{58}$

Sud je ispitivao neposrednu uzročnu vezu (causal nexus) između genocida u Srebrenici i odgovornosti Srbije samo u vrijeme kada se taj masakr dogodio. Glede davanja zadovoljštine tužitelju samom presudom, on se pozvao na svoj vlastiti presedan iz presude o Krfskom tjesnacu iz 1949. godine između Britanije i Albanije. Ali su okolnosti tih dvaju događaja duboko različite. U presudi iz 1949. Sud je uz Albaniju osudio i ponašanje Britanije zbog toga što je u albanskom teritorijalnom moru samovoljno poduzela akciju deminiranja i prikupljanja dokaza i time prekršila suverenost te zemlje. S time u vezi, Sud je tom izjavom u svojoj

56 Ibid., p. 237, para. 47(2).

57 Ibid., p. 203, para. 388.

58 Ibid., pp. 237-239, para. 471. 
presudi pružio zadovoljštinu i Albaniji. ${ }^{59}$ Ali prilikom srebreničkoga masakra, ni prije njega, nitko nije prekršio suverenost Srbije i Crne Gore.

U tim okolnostima isplata financijske kompenzacije žrtvama genocida i njihovim zakonitim nasljednicima od Srbije zbog toga što ga nije spriječila, i to možda ne u punom iznosu nego u primjerenom dijelu, nije smjela imati alternative. A zadovoljština tim žrtvama izražena u samoj toj presudi predstavlja svojevrsno izrugivanje pravdi od samoga Suda.

Uzimajući sve izloženo u obzir, Međunarodni je Sud u cjelini izrekao protiv Srbije samo deklaratornu presudu, što ju je ona od njega u svojim konačnim zaključcima u usmenom postupku sama zatražila. Srbija je s tom presudom mogla biti zadovoljna, ali čini mi se ne i Republika Srpska.

Naime, u ovoj presudi utvrđeno je sudskim putem ubojstvo oko 7000 vojno sposobnih muškaraca muslimana. Odgovornost za taj zločin genocida snose Vojska Republike Srpske i njezini politički naredbodavci. Uz to su utvrđeni masovni i teški zločini protiv čovječnosti i ratni zločini u drugim krajevima Bosne, ali se Sud smatrao nenadležnim da osim vojske i vlasti Republike Srpske utvrđuje njihovu pripisivost i u odnosu na Saveznu Republiku Jugoslaviju.

Što se tiče odgovornosti de facto vlasti Republike Srpske i njezine vojske, svi zločini tih de facto vlasti povlače po našemu mišljenju de facto odgovornost toga današnjega entiteta u Bosni i Hercegovini. Ali ni o tome se Sud nije bio nadležan izrijekom izjasniti.

\section{SRJ PROTIV DESET DRŽAVA ČLANICA NATO-a: PRESUDA OD 15. PROSINCA 2004. GODINE}

Dolazimo do nove parnice pred Međunarodnim sudom. U njoj se SRJ pojavila u svojstvu tužiteljice protiv izvorno deset država članica Sjevernoatlantskoga saveza. Radi se formalno ne o jednoj, nego o seriji parnica o Zakonitosti upotrebe sile. Tužene države bile su: Belgija, Kanada, Francuska, Njemačka, Italija, Nizozemska, Portugal, Španjolska, Ujedinjeno Kraljevstvo i Sjedinjene Države. Povod za te tužbe bilo je bombardiranje područja SRJ po NATO-snagama.

Neke se činjenice moraju prije objasniti. Nakon formalnoga ukidanja autonomije Kosova u ožujku 1989., dakle još prije raspada SFRJ, nesrpsko stanovništvo, a napose Albanci, bilo je masovno otpuštano s posla u rudnicima, drugim poduzećima, školama, bolnicama i kulturnim ustanovama. Obrazovanje na albanskom jeziku bilo je na svim razinama dokinuto, što se prije 1989. smatralo stečenim pravom toga stanovništva. Albanci na Kosovu suprotstavljali su se tim masovnim mjerama diskriminacije koje su imale odlike apartheida pasivnim otporom. Očekivalo se da će sporazumi u Daytonu i Parizu također poboljšati i

59 Cf., I. C. J. Reports 1949., p. 35. 
situaciju nedominantnih skupina u toj pokrajini. Nakon što su ta očekivanja bila izdana, organizirana je Kosovska oslobodilačka armija.

U 1998. izbili su prvi sukobi srpske policije i Armije Jugoslavije s Kosovskom oslobodilačkom armijom. Uslijedili su masovni zločini protiv albanskih civila. Rezolucija Vijeća sigurnosti UN-a 1199 od 23. rujna 1998. zabilježila je izgon više od 230.000 osoba iz njihovih domova od kojih je 50.000 ostalo bez ikakvoga skloništa i osnovnih potreba. Prvi valovi izbjeglica stigli su tada u Sjevernu Albaniju, Makedoniju i Bosnu i Hercegovinu. U tijeku tih događaja počinjeni su masakri civila, uključujući žene i djecu, napose u selu Račak.

Ta situacija bila je privremeno zaustavljena novom rezolucijom 1203 Vijeća sigurnosti od 24. listopada 1998. Sporazumno je ustanovljena Verifikacijska misija OESS-a koja je djelovala na Kosovu, a NATO je preuzeo nadzor iz zraka.

Već je prethodna rezolucija 1160 od 31. ožujka te godine podržala miroljubivo rješenje kosovskoga problema između zainteresiranih strana, zasnovano na teritorijalnoj cjelovitosti SRJ i uz pojačan položaj Kosova, koji je trebao obuhvatiti „bitno veći stupanj autonomije i istinske samouprave“ (,,a substantially greater degree of autonomy and meaningful self-administration"). Pregovori u Rambouilletu u Francuskoj u veljači i ožujku 1999. nisu doveli ni do kakvoga sporazuma na toj osnovi jer je SRJ odbacila predloženo rješenje.

Naporedo s početkom NATO-akcije 23. ožujka 1999., otpočeli su masakri civila i izgon stanovništva iz mjesta stanovanja u prije neviđenim razmjerima. $\mathrm{U}$ toj godini gotovo 800.000 izbjeglica (43\% od ukupnoga stanovništva) prognano je u Albaniju, Makedoniju, Crnu Goru i Bosnu i Hercegovinu. Ta je akcija unaprijed bila predviđena i odvijala se prema planu. Mnoga su sela bila sravnjena sa zemljom. To je bio Miloševićev luđački pokušaj da osigura neku ravnotežu između srpskoga i albanskog stanovništva u toj ,,srpskoj pokrajini““.

Valja zaključiti da nije bombardiranje NATO-a bilo uzrokom egzodusa. Izgon stanovništva u masovnim razmjerima bio je unaprijed planiran, a prethodni se planski počeo provoditi godinu dana prije. Stoga se čini da su zračni napadi NATO-a ispunili uvjete humanitarne intervencije, i to čak u odsutnosti rezolucije Vijeća sigurnosti prema Glavi VII. Povelje UN-a, koja ju je trebala odobriti. U toj situaciji ta se prisilna akcija može opravdati općim međunarodnim pravom, makar kako ga ovaj pisac shvaća. ${ }^{60}$

$*$

Vlada SRJ nastojala je omesti NATO-ovu akciju bombardiranja svoga područja podnoseći 29. travnja 1999. tužbu Međunarodnom sudu protiv deset država članica toga saveza koje su sudjelovale u toj akciji. Poput Bosne i Hercegovine u 1993.,

${ }^{60}$ Mišljenje ovoga pisca je u manjini u odnosu na druga do sada objavljena. Vidi više pojedinosti, V. Đ. Degan: „Intervencija NATO snaga protiv Savezne Republike Jugoslavije: Pravna analiza“, Politička misao, 1999, br. 4 (Zagreb), str.79-99; „Humanitarian intervention (NATO action against the Federal Republic of Yugoslavia in 1999)“, L.C. Vohrah et al. (eds): Man's Inhumanity to Man, Essays on International Law in Honour of Antonio Cassese, Kluwer Law International, 2003., pp. 233-259. 
SRJ je toga dana podnijela i zahtjev Sudu za izricanje privremenih mjera protiv svih tih država. Ali serijom naloga izdanih 2. lipnja te godine, Sud je odbio sve te zahtjeve. Tada je također ustanovio očitu odsutnost svoje nadležnosti glede tužbi protiv Španjolske i Sjedinjenih Država, i te je postupke odmah okončao. Postupak protiv preostalih osam država bio je nastavljen.

U međuvremenu je koncem 2000. došlo do spomenute promjene vlasti u Srbiji. Nova je vlast nastojala prekinuti postupak po tužbama Bosne i Hercegovine i Hrvatske protiv SRJ. Nastavak postupka protiv NATO-članica bio je ponajprije u toj funkciji jer se ne čini da je nova vlada u Beogradu vjerovala da će pred Sudom biti u stanju dokazati da su zračni udari i njihove posljedice predstavljali zločin genocida.

Pojedinačne presude po tužbama protiv preostalih osam članica NATO-a bile su izrečene 15. prosinca 2004., dakle prije presude o meritumu po tužbi Bosne i Hercegovine protiv Srbije iz 2007. Tekstovi tih osam presuda najvećim su dijelom isti, te ćemo se stoga referirati na presudu protiv Belgije.

Sud je jednoglasno zaključio da nije imao nadležnost razmatrati zahtjeve sadržane u tužbama Srbije i Crne Gore od 29. travnja 1999. ${ }^{61}$ Ali ovaj pisac ne vjeruje u to da će Sud ubuduće biti veoma ponosan na tu svoju odluku. Ona je suprotna svim prijašnjim i budućim odlukama o pravu pristupa te države Međunarodnom sudu.

U ovim parnicama u kojima se SRJ pojavila kao tužitelj, Sud je pridao važnost njezinim izjavama da prije 1. studenoga 2000. kada je bila primljena u članstvo UN-a ona nije bila članica te svjetske organizacije. Stoga u trenutku podnošenja tužbi ovome Sudu 29. travnja 1999. ona navodno nije bila stranka njegova Statuta. Sud nije bio sasvim jasan o tome je li SRJ toga dana bila i stranka Konvencije o genocidu iz 1948. godine. U tome je Sud proturječio svojoj presudi od 3. veljače 2003. o Zahtjevu za revizijom, kao i kasnijoj presudi o meritumu od. 26. veljače 2007. po tužbi Bosne i Hercegovine protiv nje.

Prijašnji položaj SRJ u UN-u između 1992. i 2000. godine predstavljao je prema toj presudi konfuznu i složenu situaciju, položaj sui generis koji je pretežito odražavao amorfni odnos o kojemu Sud još nije bio povukao konačan zaključak. Primanje SRJ u UN ,okončao je taj položaj sui generis“ ${ }^{6}{ }^{62} \mathrm{Uz}$ to, presuda iz 2003. o Zahtjevu za revizijom nije imala u odnosu na ovu parnicu snagu res judicata. ${ }^{63}$

Na temelju tih argumenata, zaključeno je: „Proizlazi da Sud nije bio otvoren Srbiji i Crnoj Gori temeljem članka 35, stavak 1. Statuta“"64 (jer nije bila njegova stranka). Ipak se čini da je to opširno obrazloženje dano ultra petitum. SRJ je zasnivala svoju tužbu iz 1999. na stavku 2. članka 35.

\footnotetext{
61 Reports 2004., p. 328, para. 129.

62 I. C. J. Reports 2004., pp. 308, 310, paras 73, 76, 78.

63 Ibid., pp. 310-311, para. 79.

${ }^{64}$ Ibid., pp. 314-315, para. 91.
} 
Uvjeti pod kojima je Sud otvoren državama nečlanicama njegova Statuta temeljem stavka 2. članka 35, jesu sljedeći: (a) moraju postojati specifične odredbe koje predviđaju nadležnost Suda u „ugovorima na snazi“ (poput npr. članka IX. Konvencije o genocidu); (b) posebne uvjete propisuje Vijeće sigurnosti; i (c) „ni u kojem slučaju iz toga ne proizlazi za stranke nikakva nejednakost pred Sudom“. Ovo posljednje znači da u slučaju nalaza da SRJ nije bila stranka Statuta Suda, njezin položaj u postupku mora pred njim biti jednak s onim ostalih stranaka Konvencije o genocidu, bilo da je ona u parnici tužiteljica ili tužena strana.

Posebne uvjete predvidjelo je Vijeće sigurnosti svojom rezolucijom 9 (1946.) koju je usvojilo još 15. listopada 1946. i nakon toga je nije mijenjalo. Temeljni uvjet je da takva država mora preuzeti obvezu da će se u dobroj vjeri podvrgnuti odlukama Suda i prihvatiti sve obveze članice UN-a iz članka 94. Povelje. ${ }^{65}$

Prema našemu skromnom uvjerenju, Sud je na koncu došao do apsurdnoga zaključka da ,ugovori na snazi“ iz stavka 2. članka 35. njegova Statuta obuhvaćaju samo one koji su bili na snazi u trenutku njegova stupanja na snagu. S obzirom na to da je Statut sastavni dio Povelje, to se zbilo 24. listopada 1945. godine, a ne u vrijeme kada je SRJ podnijela Sudu tužbu 29. travnja 1999. godine. U tome pogledu Sud je krivo interpretirao travaux préparatoires iz 1920., kada je jedan odbor Lige naroda pripremao tekst Statuta Stalnoga suda međunarodne pravde. ${ }^{66}$

Ova presuda, kojom je Sud proglasio tužbu SRJ nedopustivom, izrečena je jednoglasno. Za nju je glasovao i Milenko Kreča, sudac ad hoc iz SRJ. Ona je time došla u kontradikciju s prijašnjim i kasnijim odlukama Suda o položaju SRJ prije 2000. godine. Ispravan bi način bio da se Sud i u ovoj parnici proglasio nadležnim i iznudio od Savezne Republike Jugoslavije da kao tužiteljica sama povuče svoju tužbu. Ona bi to vjerojatno učinila nakon što je presuda o meritumu iz 2007. bila u osnovi povoljna za Srbiju. U suprotnom slučaju, ukoliko bi se postupak produljio, ona ne bi mogla dokazati da bombardiranja NATO-a predstavljaju zločin genocida.

$*$

\section{HRVATSKA PROTIV SRJ}

\section{Presuda o prethodnim prigovorima od 18. studenoga 2007.}

U tijeku napadačkoga rata u Hrvatskoj počinjeni su brojni zločini u namjeri stvaranja Velike Srbije. Ali, koliko je ovomu piscu poznato, nikada niti jedan vojni ili politički vođa nije bio optužen za genocid na području Hrvatske. Tu se nije

65 Vidi tekst I. C. J. Yearbook 2004-2005, pp. 99-100.

66 O tome je ovaj pisac potanko raspravljao, V. D. Degan: „Legal position of Serbia and Montenegro following the break-up of the SFRY“, Guerra y Paz: 1045-2009, Obra homenaje al Dr. Santiago Torres Bernárdez, Universidad Del País Vasco, 2010., pp. 159-161. 
radilo o pravnoj praznini. Kao prvo, među „krivičnim djelima protiv čovječnosti i međunarodnog prava" genocid je bio predviđen već u saveznom Krivičnom zakoniku bivše države iz 1951. godine, i to u njegovu članku 124. Time je bivša Jugoslavija izvršila svoju dužnost iz Konvencije iz 1948. kojoj je bila stranka. To krivično djelo ponavljalo se u istoj kvalifikaciji koja je odgovarala članku II. te Konvencije u novom krivičnom zakonodavstvu sve do raspada Jugoslavije.

Pri proglašenju svoje neovisnosti 8. listopada 1991., Hrvatska je preuzela tekst Krivičnog zakona SFRJ s odredbom o genocidu, ${ }^{67}$ dok je Krivični zakon Hrvatske bio ostao na snazi. Dakle, radilo se o pravnom kontinuitetu u zakonodavstvu bivše Socijalističke Republike Hrvatske s neovisnom Republikom Hrvatskom. Potom je Sabor usvojio cjeloviti tekst Kaznenoga zakona koji je stupio na snagu 1. siječnja 1998. godine. Osim što je prošao kroz jezičnu redakciju, članak 156. o genocidu i dalje po sadržaju odgovara službenim verzijama Konvencije iz 1948. godine.

Nakon što je oružani sukob u Hrvatskoj u 1995. bio okončan, a masovni zločini prestali, nije bilo novih istraga Državnoga odvjetništva u pronalaženju osumnjičenika za to kazneno djelo, pa ni u vrhu bivše JNA u Beogradu. Također ni Tužiteljstvo Međunarodnoga kaznenog tribunala za bivšu Jugoslaviju nije nikada podignulo optužnicu protiv neke osobe za zločin genocida koji bi bio počinjen u Hrvatskoj. Slobodan Milošević bio je optužen za taj zločin, ali za područje Bosne i Hercegovine.

Hrvatska je 2. srpnja 1999. uložila protiv SRJ tužbu Međunarodnom sudu u Haagu za kršenje Konvencije o genocidu, dakle nedugo nakon što je SRJ tužila deset članica NATO-a 29. travnja te godine u povodu bombardiranja svog područja. U obje te parnice tužitelji su se pozivali na članak IX. Konvencije o genocidu. Za pravne stručnjake koji nisu bili uključeni u taj pothvat hrvatska tužba predstavljala je iznenađenje.

U presudi o prethodnim prigovorima izrečenoj 18. studenoga 2008. Sud se proglasio nadležnim i odbacio je gotovo sve prigovore SRJ. Ipak, drugi prigovor tužene države prema kojemu su navodno nedopustivi zahtjevi Hrvatske glede djela i propusta koji su se zbili prije navodnoga stvaranja SRJ 27. travnja 1992., Sud je spojio s razmatranjem merituma tužbe i time je o njemu odložio svoju odluku. Naveli smo već da su najveći i najmasovniji zločini sa srpske strane na tlu Hrvatske bili počinjeni negdje do konca 1991. U stvari je Sud u ovoj parnici ponovno promijenio svoj stav u odnosu na presude u parnicama protiv članica NATO-a iz 2004. godine.

Kao i u prijašnjim presudama, Sud je ponovio da sve njegove odluke koje su prethodile ovoj parnici nemaju za ovu parnicu snagu res judicata. „U mjeri u kojoj odluke sadrže nalaze o pravu, Sud će ih uzimati u obzir kao što uzima sve prijašnje

${ }^{67}$ Zakon o preuzimanju Krivičnog zakona Socijalističke Federativne Republike Jugoslavije bio je usvojen u Saboru još 26. lipnja 1991., ali je objavljen u Narodnim novinama br. 53 na str. 1528-1531, od 8. listopada te godine, kada je stupio na snagu. 
odluke, tj. iako te odluke ni na koji način ne obvezuju Sud, on neće odstupati od svoje utvrđene prakse osim ako za to iznađe posebne razloge." ${ }^{68}$

Čini nam se da sam Sud može narušiti stabilnost i predvidljivost svoje cjelokupne prakse ukoliko se njegovi posebni razlozi za česte promjene u pravnoj kvalifikaciji istih činjenica ne čine dovoljno uvjerljivima i pravnički opravdanima. Mnogi nastavnici diljem svijeta predaju disciplinu međunarodnoga prava onakvu kakvu tumače i primjenjuju taj Međunarodni sud i međudržavna arbitraža. To se ponajprije čini zbog uvjerljivosti i dugotrajne dosljednosti te prakse. A ako uslijed nekih izvanpravnih motiva opadne koherentnost te „utvrđene prakse“, to može biti štetno po čitavo međunarodno pravo kao disciplinu.

Srbija se u ovoj parnici u svojstvu tužene države čvrsto oslanjala na nalaz Suda iz njegove presude iz 2004. godine protiv zemalja NATO-a, da prije 1. studenoga 2000. godine ona nije bila stranka Statuta Suda. Očekivala je da će se, kao i u prijašnjoj parnici, u pogledu tužbe Hrvatske Sud proglasiti nenadležnim. Ali se dogodilo drukčije.

Ovoga puta Sud je utvrdio svoju nadležnost temeljem stavka 1. članka 33. svoga Statuta. Naglasio je da njegov prijašnji nalaz, zasnovan na stavku 2, nije u ovoj parnici imao snagu res judicata. Uz to, Hrvatska je zamolila Sud da ponovno razmotri i izmijeni tumačenje koje je pridao članku 33(2) svog Statuta u presudi iz 2004., u smislu da „ugovori na snazi“" obuhvate i ugovore sklopljene nakon stupanja na snagu Statuta. ${ }^{69}$

Sud je ovoga puta ustanovio da je od 1. studenoga 2000. do izricanja ove presude tužena strana (SRJ) bila stranka Statuta temeljem svoga članstva u UN$\mathrm{u}, \mathrm{tj}$. temeljem članka 93., stavak 1. Povelje. Stoga je nesporno da su u vrijeme izricanja te presude i Hrvatska i Srbija imale pravo pristupa Sudu temeljem članka 33., stavak 1. Statuta. ${ }^{70}$ Ali ono što je bilo nesporno u vrijeme izricanja ove presude bilo je u prijašnjoj parnici za razdoblje prije 1. studenoga 2000. sporno.

U ovoj parnici Hrvatska se pozvala na presedan iz prakse dvaju haških sudova nastao u sporovima Mavrommatis Palestine Concessions iz 1924. Prema tome presedanu, ukoliko u vrijeme otpočinjanja postupka uvjeti za nadležnost Suda nisu u potpunosti zadovoljeni, ali se oni naknadno zadovolje, tužitelj može u bilo koje vrijeme podnijeti novu tužbu koja će u tome pogledu biti nepobitna. Na prigovor Srbije da Sud nije primijenio „doktrinu Mavrommatis“ u presudi iz 2004., Sud je na svoju ruku ustvrdio da Srbija i Crna Gora nisu imale namjeru podnijeti novu tužbu. Ali novu tužbu u ovoj parnici nije podnijela ni Hrvatska. Dakle, stvarno bi bilo bolje da se Sud u svojoj presudi iz 2004. proglasio nadležnim, jer tada do takvih vratolomija ne bi moralo doći.

\footnotetext{
68 I. C. J. Reports 2007., pp.17-18, para. 53.

69 Ibid., p. 20, para. 64.

70 Ibid., p. 25 , para. 77.
} 
Osim što je Sud spojio pitanje odgovornosti Srbije za djela počinjena prije 27. travnja 1992. s razmatranjem merituma spora, bilo je i drugih pitanja koja su čekala na konačni sudski pravorijek.

U ovoj se parnici Savezna Republika Jugoslavija nije usudila pozivati na svoju rezervu danu pri svom pristupu (ili sukcesiji) Konvenciji o genocidu iz 1948. u svojstvu navodno nove države. Kako smo prije naveli, u aktu o notifikaciji od 6. ožujka 2001. ona je dala restriktivnu izjavu prema kojoj se ne smatra obveznom člankom IX. te Konvencije prije nego što dade svoj pristanak ,glede bilo kojega spora“. Unatoč toj izjavi, ona je dalje sudjelovala u sve tri parnice koje su bile u tijeku.

U ovoj presudi iz 2007. Sud je ustanovio da je SRJ obvezna Konvencijom o genocidu otkako je u Deklaraciji od 27. travnja 1992. preuzela en bloc sve ugovore (bivše) SFRJ ${ }^{71} \mathrm{~S}$ obzirom na to da se sama SRJ odrekla zahtjeva za identitetom i kontinuitetom s državom prethodnicom, ona se logično morala odreći i od te izričite izjave u tome proglasu. Ali je ona od tada tu Deklaraciju tumačila kao akt svojega nastanka kao nove države. Za Sud je tada bio jedino važan navod o preuzimanju pravnih obveza države prethodnice. SRJ, dakle, nije insistirala na svojoj rezervi od 6. ožujka 2001. prema kojoj je ništa ne obvezuje prije toga datuma, ali je u ovoj parnici odbijala svoju odgovornost za djela prije 27. travnja $1992 .{ }^{72}$

Hrvatska je u ovoj parnici ustvrdila da „činjenica što se SRJ samo formalno proglasila 27. travnja 1992. ne znači da akti koji su se zbili prije toga datuma ne mogu njoj biti pripisani“. U tome pogledu ona se pozvala na članak 10(2). nacrta članaka Komisije za međunarodno pravo o odgovornosti države u kojemu je predviđeno da ,ponašanje nekog ustaničkog ili drugoga pokreta koji uspije ustanoviti novu državu... smatrat će se prema međunarodnom pravu djelom te nove države“". ${ }^{73}$

Dakle, i u ovoj parnici radilo se o važnom pitanju položaja SRJ u odnosu na SFRJ koja je prestala postojati. Sud je o tome pitanju odložio svoju odluku.

Različito je pitanje od gornjega je li Hrvatska mogla u postupku o meritumu koji je slijedio dokazati zločin genocida na svome državnom području u svjetlosti visokih kriterija za utvrđivanje dolus specialis iz presude iz 2007. u povodu tužbe Bosne i Hercegovine protiv SRJ. Ali uspoređujući sve odluke Suda u parnicama u kojima je SRJ, Srbija i Crna Gora, ili sama Srbija bila uključena, ne možemo se oteti utisku da su akcije NATO-a bile isključene iz nadležnosti Suda iz razloga koji nisu strogo pravne naravi.

\footnotetext{
71 Ibid., p. 33, paras 98, 99.

72 Ibid., p. 41, para. 120.

73 Ibid., p. 43, para. 125.
} 


\section{Presuda o meritumu od 26. veljače 2015.}

Napokon, i ova presuda o meritumu u povodu tužbe Hrvatske potvrđuje stanovište Međunarodnoga suda o domašaju njegove nadležnosti:

„Sud podsjeća da je njegova nadležnost u ovoj parnici zasnovana na članku IX. Konvencije o genocidu i da on stoga može odlučivati jedino u granicama propisanima tim instrumentom. Njegovi su zaključci stoga bez utjecaja na svako drugo pitanje o mogućoj odgovornosti stranaka glede kršenja drugih međunarodnih obveza koje ne proizlaze iz same Konvencije (o genocidu). U slučajevima da su se takva kršenja dogodila, stranke ostaju odgovorne za njihove posljedice. Sud ohrabruje stranke da produlje sa suradnjom kako bi se žrtvama tih kršenja ponudila prikladna obeštećenja i da tako konsolidiraju mir i stabilnost u regionu.“"74

U odnosu na prethodnu presudu, Sud je dalje precizirao, drugim riječima suzio, svoju nadležnost iz članka IX. Konvencije navodeći da se ona ne odnosi na tvrdnje o kršenju međunarodnoga običajnog prava glede genocida. Sama Konvencija sadrži načela koja su u isto vrijeme dio međunarodnoga običajnog prava, ali je nadležnost Suda iz članka IX. ograničena na „tumačenje, primjenu i provedbu ove Konvencije“ i na „odgovornost neke države za genocid ili za bilo koje drugo djelo navedeno u članku III“، ${ }^{75}$

Hrvatska se u svojoj tužbi pozivala na zločine počinjene između 1991. i 1995. godine kao na kršenje Konvencije o genocidu za koje je odgovorna tužena strana. U svojoj protutužbi podnesenoj 11. rujna 2002., koju je Sud prihvatio jer je ispunjavala formalne uvjete iz članka 80. njegova Poslovnika, Srbija je ustvrdila da su hrvatske snage u tijeku akcije „Oluja“ u kolovozu 1995. počinile zločin genocida prema srpskom stanovništvu u „Krajini““.

Nakon presude o prethodnim prigovorima iz 2007., Sudu je preostalo da odluči o odgovornosti za srpske zločine počinjene u Hrvatskoj prije 27. travnja 1992. Hrvatska se pozvala na stavak 2. članka 10. Nacrta pravila o odgovornosti država Komisije za međunarodno pravo, prema kojemu:

„Ponašanje nekoga ustaničkog ili drugog pokreta koji uspije uspostaviti novu državu na dijelu područja otprije postojeće države, ili na nekom području pod njezinom upravom, smatrat će se prema međunarodnom pravu djelom te nove države."

Hrvatska je ustvrdila da ta odredba čini dio međunarodnoga običajnog prava čak ukoliko je SRJ nastala tek 27. travnja 1992. Sud je taj navod odbio smatrajući da je ta odredba neprimjenjiva na SRJ, te da ona uređuje pitanje pripisivosti akata novoj državi, a ne njezine pravne obveze. S time u vezi, citirao je i članak 13. toga Nacrta prema kojemu: „Djelo države ne predstavlja povredu njezine

74 I. C. J. Reports 2015., para. 523.

75 I. C. J. Reports 2015., para. 87. 
međunarodne obveze osim ako je država vezana tom obvezom u trenutku kada se djelo dogodi."

Kako smo prije navodili, glavni masovni zločini na području Hrvatske sa srpske strane zbili su se do konca 1991. godine. Ukoliko bi se zahtjev Srbije ratione temporis uvažio, hrvatska tužba ne bi imala mnogo smisla, a ostao bi loš utisak da je Sud izbjegao odlučivanje o srpskim zločinima iz čisto formalnih razloga. Za odbacivanje srpskoga prigovora glasovalo je deset sudaca, ali ga je šest njih bilo sklono prihvatiti. Većina je bila solidna, ali čitava ova priča ukazuje na to da su suci iz nekih država pod utjecajem prošlih događaja u svojim zemljama. Oni su ratione temporis skloni restriktivno tumačiti odredbe Konvencije o genocidu kako se njihove zemlje ne bi uplele u sporove o nekim događajima iz prošlosti.

Većina u Sudu usvojila je salomonsko rješenje. Tim sucima je bilo jasno da ni Hrvatska, a ni Srbija u svojoj protutužbi, nisu bile u stanju dokazati dolus specialis za zločine koji su bili predmetom njihovih tužbi. Tako, uz navod koji je bio protiv retroaktivne primjene članka IX. Konvencije, većina sudaca donijela je odluku koja nije sasvim u skladu s njime. Sud je prizvao supsidijarni argument Hrvatske prema kojemu: kada je SRJ 27. travnja 1992. naslijedila ugovorne obveze SFRJ, ona je također naslijedila njezinu već postojeću odgovornost za kršenja Konvencije koja su bila počinjena.

Iz toga je sam Sud izveo neka pitanja: (i) jesu li djela koja Hrvatska navodi (zaista) počinjena i ako jesu da li su suprotna Konvenciji; (ii) ukoliko se to utvrdi, jesu li ta djela bila pripisiva SFRJ u vrijeme njihova počinjenja i da li su tada povlačila njezinu odgovornost; i (iii) ako je odgovornost SFRJ bila angažirana, je li je SRJ naslijedila? ${ }^{77}$

Na temelju tih promišljanja, Sud je odlučio da na temelju članka IX. Konvencije on ima nadležnost ispitati tužbu Hrvatske glede djela od prije 27. travnja 1992. ${ }^{78}$ Sud je tako u ovoj presudi nabrojao i ispitao sve navode iz tužbe Hrvatske.

Za obrazovane pravnike ne predstavlja nikakvoiznenađenje što se Međunarodni sud u ovoj presudi po tužbi Hrvatske čvrsto držao svojih zaključaka iz presude iz 2007. po tužbi Bosne i Hercegovine. U svim navodima iz podnesene tužbe Sud je najprije procijenio predstavljaju li neko od djela zabranjenih u članku II. Konvencije o genocidu (actus reus) i je li tužitelj dokazao njihovo počinjenje. Potom je posebno procjenjivao je li tužitelj dokazao namjeru počinitelja ,da se u cijelosti ili djelomično uništi neka nacionalna, etnička, rasna ili vjerska skupina“

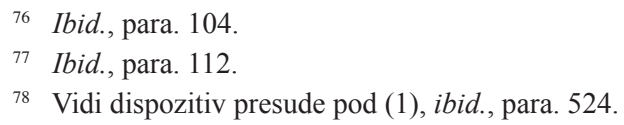


(mens rea). ${ }^{79}$ Tako je Sud postupio po navodima tužbe Hrvatske kao i po onima iz protutužbe Srbije.

Sud se i ovoga puta oslanjao na činjenice koje je utvrdio Međunarodni kazneni tribunal za bivšu Jugoslaviju, s tom razlikom što taj Tribunal nije izrekao ni jednu presudu pojedincima za počinjeni genocid u Hrvatskoj. Zbog toga nije bilo dokaza o postojanju genocidne namjere, nego samo onih o činjenicama.

U ovoj presudi ponovljeni su navodi iz presude izrečene 2007. da protjerivanje stanovništva s nekoga prostora kako bi se on učinio „etnički homogenim“ ne predstavlja genocid ako nije dokazano da su se vršila sustavna ubojstva s genocidnom namjerom. Dakle, sâmo protjerivanje ne čini zločin genocida. Tu se Sud dosljedno držao svoga krajnje restriktivnog tumačenja propisâ iz Konvencije o genocidu iz 1948. godine. To za državu tužiteljicu nije smjelo predstavljati iznenađenje jer bi nakon 2007. godine drukčija očekivanja implicirala da će Sud različito tretirati Hrvatsku od Bosne i Hercegovine kao žrtava zločina.

U prethodnoj parnici nametnulo se pitanje pripisivosti Saveznoj Republici Jugoslaviji zločina genocida počinjenoga u Srebrenici i okolici, dakle na području susjedne države Bosne i Hercegovine. U ovoj parnici takvo se pitanje nije postavljalo. Hrvatska je za sve zločine bivše „Jugoslovenske narodne armije“ i paravojnih srpskih snaga optužila SRJ, a Sud je ratione temporis odbio njezin zahtjev za njezinom odgovornošću samo za djela počinjena od 27. travnja 1992. Djela počinjena u akciji „Oluja“" u 1995. iz protutužbe Srbije mogla su se pripisati samo Hrvatskoj.

Tako, jednako kao i u presudi iz 2007. po tužbi Bosne i Hercegovine, Sud je najprije obradio actus reus zločina o kojima je Hrvatska podnijela dokaze, i to po svakoj točki iz članka II. Konvencije iz 1948., te po oblastima (regijama) Hrvatske. S obzirom na to da Hrvatska nije tužila SRJ za zločin iz točke (e) ,premještanje djece iz jedne skupine u drugu“", taj se zločin u presudi nije ni mogao uzeti u obzir.

Pod točkom (a) ,ubojstvo članova skupine“, Sud je naveo mjesta počinjenih zločina po oblastima: Istočna Slavonija (Vukovar s okolicom, Bogdanovci, Lovas, Dalj); Zapadna Slavonija (Voćin); Banovina/Banija (Joševica, Hrvatska Dubica s okolicom); Kordun (Lipovača); Lika (Saborsko, Poljanak); Dalmacija (Škabrnja s okolicom, Bruška); te Dubrovnik. ${ }^{80}$

Sud je ustanovio ne samo velik broj ubojstava koje su počinile JNA i srpske snage, nego i to da su žrtve bili u ogromnoj većini Hrvati kao zaštićena skupina. Time je on utvrdio da je actus reus genocida iz točke (a) Konvencije ustanovljen. Sud nije sastavljao potpuni spisak počinjenih ubojstava. ${ }^{81}$

79 Pri tome je, za razliku od presude iz 2007., Sud ovoga puta primijenio terminologiju iz Rimskoga statuta stalnoga Međunarodnog kaznenog suda iz 1998.

80 Ibid., paras 209-294.

81 Ibid., para. 295. 
Pod točkom (b) „,nanošenje teške tjelesne ili psihičke povrede članovima skupine" navode se Istočna Slavonija (bombardiranje i osvajanje Vukovara, zauzeće i evakuiranje vukovarske bolnice; Bapska, Tovarnik, Berak, Lovas, Dalj); Zapadna Slavonija (Kusonje, Voćin, Đulovac); te Dalmacija (Knin). ${ }^{82}$

I tu je Sud ustanovio da su JNA i srpske snage nanosile u tijeku sukoba ozljede Hrvatima u više spomenutih lokaliteta, uključujući i Dubrovnik, i da su zbog toga krive za čine maltretiranja, mučenja, seksualnog nasilja i silovanja. Materijalni element genocida je time po toj točki utvrđen, ${ }^{83}$ ali po mišljenju Suda, Hrvatska nije dokazala da je nestanak osoba predstavljao za njihovu rodbinu psihičku patnju kakva se podrazumijeva u točki (b) članka II. Ipak je u presudi zabilježeno da su obje strane izrazile volju da u interesu rodbine rasvijetle sudbinu nestalih osoba.

Pod točkom (c) ,namjerno podvrgavanje skupine takvim uvjetima života koji bi trebali dovesti do njezinoga potpunog ili djelomičnog uništenja“, navode se čini silovanja, uskraćivanje stanovništvu hrane i medicinske skrbi, sustavno oduzimanje stanova i nasilno protjerivanje; ograničenja u kretanju; nasilno nošenje znakova etničke pripadnosti; pljačka dobara Hrvata; uništavanje i pljačka kulturnoga naslijeđa; te prisilni rad. $^{84}$

Sud je razmotrio hrvatske dokaze o gornjim činima kao o djelima genocida zabranjenima u točki (c) članka II. Konvencije. Iako je priznao da su neke optužbe u nekim lokalitetetima Istočne Slavonije dokazane, u presudi je ipak zaključeno da Hrvatska nije dokazala da su te čine koji predstavljaju actus reus genocida počinile JNA i srpske snage u takvom obujmu da su mogli fizički uništiti hrvatsku populaciju ${ }^{85} \mathrm{U}$ toj točki ova se presuda razlikuje od one po tužbi Bosne i Hercegovine iz 2007. godine.

Navode se i podaci glede točke (d) ,nametanje takvih mjera kojima se želi spriječiti rađanje u okviru skupine". U pitanju su bili čini seksualnoga nasilja, silovanja pa i kastriranja. I tu je Sud bio restriktivan. Zaključio je da JNA i srpske snage nisu počinile ta djela u takvom obujmu da bi ona mogla spriječiti rađanje u okviru hrvatske skupine. Time po odluci Suda actus reus genocida po točki (d) nije dokazan. ${ }^{86}$

Na koncu je Sud potvrdio da je u potpunosti uvjeren u to da su JNA i srpske snage u više gore nabrojanih lokaliteta počinile čine zabranjene u točkama (a) i (b), te da je materijalni element genocida (actus reus) time dokazan. ${ }^{87}$

Ovaj dio presude opširan je i obuhvaća gotovo 200 paragrafa od ukupno njih 524, na gotovo 40 stranica teksta. Sud je citirao i prihvaćao nalaze iz praktično svih presuda Međunarodnoga kaznenog tribunala za bivšu Jugoslaviju koji su se

\footnotetext{
82 Ibid., paras 296-359.

83 Ibid., para. 360.

84 Ibid., paras 361-393.

35 Ibid., para. 394.

86 Ibid., paras 395-400.

87 Ibid., para. 401.
} 
odnosili na ocjenu i kvalifikaciju iznesenih navoda u hrvatskoj tužbi. Svakome tko dovoljno vlada engleskim ili francuskim jezikom valja preporučiti da dijelove te presude koji ga zanimaju pročita i da o njima stvori vlastito uvjerenje. Do svih odluka ovoga Suda i Kaznenoga tribunala u Haagu moguće je doći na internetu bez ograničenja i potpuno besplatno.

Valja odati priznanje hrvatskim vlastima koje su se trudile da prikupe i pred Sud iznesu sve podatke o zločinima za koje su vjerovale da predstavljaju genocid. Ali, kao i u parnici po tužbi Bosne i Hercegovine iz 2007., Hrvatska nije bila u stanju iznijeti dokaze koji bi uvjerili sam Sud o postojanju genocidne namjere počinitelja, tj. da su svi ti zločini na nekom prostoru Hrvatske počinjeni s namjerom da se u cijelosti ili djelomično fizički unište Hrvati kao zaštićena skupina. Slijedilo je, dakle, mnogo teže pitanje od prethodnoga, utvrđivanje dolus specialis.

$\mathrm{U}$ nedostatku direktnoga dokaza genocidne namjere (npr. izričite politike $\mathrm{u}$ tome smislu), Sud je razmotrio moguće postojanje obrasca ponašanja koji se može jedino objasniti postojanjem namjere da se (fizički) uništi značajan dio hrvatske populacije. Sud u toj presudi smatra da Hrvatska to nije dokazala. Cilj srpskih zločina bio je etničko čišćenje osvojenih prostora od Hrvata kako bi se ujedinila „srpska područja“" u Hrvatskoj i Bosni i Hercegovini sa Srbijom i stvorio jedinstven homogeni teritorij putem istjerivanja Hrvata i drugih nesrba. Memorandum Srpske akademije nauka i umetnosti koji je citirala Hrvatska nije službeni dokument i on sigurno ne podrazumijeva uništenje Hrvata. ${ }^{88}$

U objašnjenju toga zaključka Sud je po našemu mišljenju bio brutalan. Glede zbivanja u Vukovaru kojima je Hrvatska pridala značajnu pozornost, navedeni su podaci iz presude Kaznenoga tribunala o Mrkšiću da su brojni Hrvati bili evakuirani i da postojanje genocidne namjere nije jedini razuman zaključak. Zločini u Vukovaru, uključujući maltretiranja u Ovčari, nisu počinjeni u namjeri uništenja članova skupine, nego njihovo kažnjavanje kao neprijatelja u vojnom smislu. Nakon pada toga grada, civili su bili evakuirani u Hrvatsku ili u Srbiju, a ni svi borci nisu bili smaknuti. Neki su bili transportirani u Srijemsku Mitrovicu kao ratni zarobljenici. ${ }^{89}$

Naše je mišljenje da je Sud tu trebao biti uravnoteženiji. Ako tim djelima i nije priznao odlike genocida, mogao je za te slučajeve makar obiter dicta ustanoviti da se radilo o ratnim zločinima i o zločinima protiv čovječnosti, i kao takve jasno ih osuditi. Zarobljeni borci nisu uživali pogodnosti iz Treće ženevske konvencije o postupanju s ratnim zarobljenicima iz 1949. godine. Oni su bili mučeni, ponižavani, a neki od njih i ubijeni.

Na temelju svega gornjega, Sud je došao do zaključka da Hrvatska nije dokazala dolus specialis glede čina koji predstavljaju actus reus genocida u smislu točaka

88 Ibid., paras 419-430.

89 Ibid., para. 436. 
(a) i (b) članka II. Konvencije. Sud je tomu dodao da tužitelj Kaznenoga tribunala u Haagu nije nikada optužio nekoga pojedinca za taj zločin u Hrvatskoj. ${ }^{90}$

$*$

Potom su temeljem istih kriterija razmotreni navodi iz protutužbe Srbije o navodnom genocidu počinjenom protiv srpskih civila u vojnoj akciji „Oluja“ u kolovozu 1995. godine. Srbija je u njoj ustvrdila da su hrvatske snage u tijeku te akcije ubijale srpske civile pri prekomjernom bombardiranju gradova Krajine (Knin, Benkovac, Gračac i Obrovac, te neka susjedna mjesta u Bosni); da su one prognale ogroman broj civila; da su otvarale vatru na kolone izbjeglica; da su maltretirale Srbe u tijeku i nakon te operacije; te da su počinile ogromna razaranja i pljačku srpske imovine. Po mišljenju Srbije, time je Hrvatska prekršila točke (a), (b) i (c) članka II. Konvencije o genocidu. ${ }^{91}$

U utvrđivanju činjenica, Sud se napose oslonio na nalaze Tribunala u Haagu u slučaju Gotovina. Pridao je punu vjerodostojnost nalazima žalbenoga vijeća, kao i onima u presudi prvostupanjskog vijeća koje ovo nije potom ukinulo.

Sud je tako potvrdio prijašnji nalaz da nije bilo prekomjernoga bombardiranja gradova i da ta bombardiranja nisu imala za cilj ubijanje srpskih civila. ${ }^{92}$ To se odnosilo i na navod o progonu srpskih civila. „Vrhovno vijeće obrane Republike Srpske Krajine" donijelo je odluku o njihovoj evakuaciji. ${ }^{93}$ Ali, po mišljenju Suda, izneseni su dovoljni dokazi o otvaranju vatre na kolone izbjeglica, ${ }^{94}$ i o ubijanju srpskih civila. ${ }^{95}$ Glede optužbi za maltretiranje Srba i za razaranje i pljačku njihove imovine, takvi pojedinačni slučajevi nisu dovoljno ozbiljne naravi ili dokazi nisu bili dostatni. ${ }^{96}$ Time je Sud došao do zaključka da su u tijeku akcije „Oluja“ počinjeni zločini iz točaka (a) i (b) članka II. Konvencije o genocidu, ali ne i ogromna razaranja imovine koja bi potpadala pod točku (c).

U dokazivanju genocidne namjere Srbija je isticala transkript sastanka na Brijunima uoči akcije „Oluja“, kojemu je predsjedao predsjednik Republike Franjo Tuđman. U pogledu toga sastanka, Sud je zaključio da su hrvatski vođe predvidjeli da će vojni napad koji su pripremali imati za posljedicu egzodus ogromne većine srpske populacije iz Krajine. Oni su možda bili zadovoljni s takvim posljedicama i nisu ništa učinili da spriječe egzodus. Ali čak ako je to tumačenje ispravno, ono je daleko od toga da bi Sudu dopustilo zaključak o postojanju specifične namjere

\footnotetext{
$90 \quad$ Ibid., paras 440, 441.

91 Ibid., paras 452, 462.

92 Ibid., para. 475.

3 Ibid., para. 476.

Ibid., paras 484-485.

95 Ibid., para. 493.

9 Ibid., paras 494-498.
} 
koja čini genocid. ${ }^{97} \mathrm{Tu}$ je Sud u tumačenju toga dokumenta došao do istoga zaključka kao i žalbeno vijeće Tribunala u Haagu.

$\mathrm{Na}$ temelju te ocjene, Sud je zaključio da dolus specialis nije dokazan i da u tijeku akcije „Oluja“ nije počinjen genocid protiv srpskoga stanovništva u Hrvatskoj.

Tako je Sud u dispozitivu svoje presude s petnaest glasova za i dva protiv (sudac Cançado Trindade i sudac ad hoc Vukas), odbacio tužbu Hrvatske. Sud je uz to jednoglasno (uključujući glas suca ad hoc Kreće) odbacio i protutužbu Srbije.

\section{KRATAK ZAKLJUČAK}

U Odluci o prethodnim pitanjima na mišljenja br. 8, 9 i 10 od 4. srpnja 1992. (Badinterova) Arbitražna komisija odbacila je tvrdnje Srbije i Crne Gore o njezinoj nenadležnosti da se očituje o pitanjima koja su joj zadana, i to sljedećim navodom:

„3. Kao što je Međunarodni sud istakao, još od spora Alabama ${ }^{98}$ općenito je prihvaćeno, u skladu s prijašnjim presedanima, da je u nedostatku suprotnog sporazuma svaki međunarodni tribunal sudac svoje vlastite nadležnosti i da ima moć da u tu svrhu tumači akte koji određuju tu nadležnost... (presuda od 18. studenoga 1953., Spor Nottebohm, Prethodni prigovori, Rec. 1953., p.119). Stoga ovoj Komisiji pripada da se izjasni o svojoj nadležnosti.“

Članak 36(6). Statuta Međunarodnoga suda potvrđuje gornje pravilo sljedećim navodom: „U slučaju spora o nadležnosti Suda odlučuje Sud“. Radi se o načelu „compétence de la compétence“, koje je potvrđeno u brojnim odlukama Međunarodnoga suda, kao i u međudržavnoj arbitraži.

Stoga, kada je taj Međunarodni sud baš u svakoj svojoj odluci ponavljao stav da je njegova nadležnost ograničena člankom IX. Konvencije o genocidu iz 1948., svaki pravnik morao je zaključiti da je ta odluka Suda o njegovoj vlastitoj nadležnosti konačna i da je u pitanju res judicata. To je trebalo uvažiti barem od presude o prethodnim prigovorima po tužbi Bosne i Hercegovine iz 1996. godine. Otada je bilo iluzorno očekivati da će Sud naknadno proširiti svoju nadležnost na odgovornost država za zločin agresije, na zločine protiv čovječnosti i ratne

97 Ibid., para. 505.

98 Radilo se o prvoj presudi tzv. „,moderne arbitraže“, izrečenoj 14. rujna 1872. između Sjedinjenih Država i Britanije. U pitanju su bili izgradnja i opremanje ratnoga broda pod tim imenom u britanskim brodogradilištima, a po narudžbi južnjačke Konfederacije u Američkom građanskom ratu (1861. - 1865.). Britanija je za tu povredu neutralnosti platila državi tužiteljici u ono doba ogromnu svotu od 15.500.000 američkih dolara. 
zločine, uključujući tu i nehumanu praksu etničkoga čišćenja prostora u Hrvatskoj i Bosni i Hercegovini, ukoliko ta djela nemaju elemente genocida iz Konvencije.

Gornje ne znači da svi ti zločini nisu bili počinjeni, a mnoge od njih potvrdio je sam Sud, ili da se tu uopće ne radi o međunarodnim zločinima. To samo znači da Sud za njih nije nadležan temeljem članka IX. Konvencije.

Nakon što je u presudi o meritumu po tužbi Bosne i Hercegovine iz 2007. Sud krajnje restriktivno protumačio i primijenio materijalne odredbe Konvencije iz 1948. o genocidu, više nije bilo nikakvih stvarnih izgleda da će on drukčije tretirati zločine počinjene u Hrvatskoj za koje tužitelj nije u stanju dokazati genocidnu namjeru počinitelja, i da će u kriterijima dokazivanja postupiti blaže. Taj stav Suda može se s doktrinarnog i moralnog stajališta kritizirati, ali država koja namjerava tužiti drugu državu za genocid mora unaprijed biti svjesna tih ograničenja koja je postavio sam Sud i u skladu s njima donositi svoje odluke glede moguće tužbe. Država tužiteljica ne smije se prepuštati iluziji da je taj glavni sudski organ UN-a nalik na neki „Božji sud“ koji nema ograničenja u svojim nadležnostima.

Dakle, u pitanju su neka od temeljnih načela međunarodnoga pravosuđa. S obzirom na to da je Hrvatska u srpnju 1999. podnijela tužbu protiv SRJ za genocid na svome području i da čak ni nakon 2007. nije od nje odustala, zaslugom pravnika u vladinoj službi ona je vodila unaprijed izgubljeni spor koji nikako nije mogla dobiti.

To ponašanje tih pravnika može se protumačiti kao njihovo nepoznavanje nekih temeljnih načela međunarodnoga prava i kao rezultat lošega obrazovnog procesa na fakultetima na kojima su stekli formalnu kvalifikaciju. Ali čak i ako su poznavali tu materiju, oni su možda bili lijeni da savjesno prouče sve odluke Međunarodnoga suda o pitanjima genocida čije smo obrise ovdje nastojali prikazati i da iz njih povuku pouke. Najvjerojatnije je u pitanju treće: političari su donosili sve odluke glede podnošenja ove tužbe i nastavka parnice protiv SRJ, a pravnici u njihovoj službi iz osobnih su se interesa trudili da s tim odlukama ne dođu u sukob, nego da u njihovu ostvarenju sudjeluju bez obzira na krajnji ishod.

Angažirani su i strani odvjetnički uredi i neki strani eksperti kao pojedinci. Ali neki od njih nisu svojim objavljenim publikacijama dokazali da su kompetentni u svim aspektima ove parnice što smo je u ovoj raspravi nastojali opisati. Na koncu su od toga jalovog parničenja materijalnu korist izvukli, ne žrtve zločina, nego stranci sa svojim visokim honorarima čija isplata i visina ne ovise o uspjehu tužbe. Naša bi Vlada trebala sačiniti cjelovitu analizu svih troškova stranih konzultanata i razmotriti učinkovitost njihova posla. Uvjereni smo da bi se tu makar za ubuduće mogle postići značajne uštede u proračunu, i to u korist sredstava namijenjenih znanstvenim istraživanjima domaćih institucija. 


\section{THE CRIME OF GENOCIDE BEFORE THE INTERNATIONAL COURT OF JUSTICE}

The I.C.J. has dealt so far with three cases in which its jurisdiction was claimed to be based on Article IX of the 1948 Genocide Convention. In all these cases was involved the Federal Republic of Yugoslavia (FRY). It appeared as defendant in cases on applications of Bosnia and Herzegovina and Croatia. Both of them were time consuming and costly for applicants. The case on application of Bosnia-Herzegovina lasted between 20 March 1993 and 26 February 2007 when the final Judgment on the merits was delivered. That in which Croatia was applicant lasted between 2 July 1999 and issuing of the Judgment on merits on 26 February 2015. The FRY submitted its application against NATO members on 29 April 1999 during the bombardment of its territory, and the Court issued the Judgment refusing its jurisdiction to entertain this series of cases on 15 December 2004.

The result of all these litigations was the ascertainment of the crime of genocide according to the 1948 Convention only in Srebrenica in Bosnia-Herzegovina. In no case the victims of this crime or their heirs got any pecuniary or other satisfaction.

In this paper are discussed three important issues.

(a) The first issue is referred to the identity of the FRY which during these proceedings changed its appellation and legal position. As a union of States it ended by the proclamation of Montenegro as an independent State on 3 June 2006. Since then Serbia assumed the responsibilities of the former union.

The Judgment of the Court of 2004 against the NATO members was in its result and motivation in sharp contradiction with all other rulings of the Court on the same facts. The reasons for the confusing situation in this respect lay in poor functioning of the Legal Adviser of the UN, in contradictory decisions by the Security Council and the General Assembly, but most of all in shifting of legal position of the FRY itself. In a parliamentary Declaration of 27 April 1992 it claimed to keep identity and continuity of the SFRY as the predecessor State on a reduced territory. However, it was admitted into the UN Membership on 1st November 2000 as a new State. Since then it took its Declaration of 1992 as an act of its independence that what is in contradiction with its own text. On this basis it refused any responsibility for international crimes committed before 27 April 1992 . The Court itself was unable to find uniform and reasonable answers in all aspects of this confusing situation.

(b) However unlike the above decisions, the Court was consistent in all its rulings by which it restricted its own jurisdiction to Article IX of the 1948 Genocide Convention. Hence it refused to deal with allegations of applicants concerning commission of aggression, of crimes against humanity and war crimes, including acts of ethnic cleansing which do not fall within Article II of the Convention.

Bosnia-Herzegovina, and latter on Croatia, did not take into account that the I.C.J. is master of its own jurisdiction and that all its decisions on this subject matter are res judicata. They probably believed that the problem was of political nature and that they will be able to persuade the Court to extend its jurisdiction in order to protect the victims of conflicts. This did not happen.

(c) After the Court in its Judgment on merits of 2007 on the application of Bosnia-Herzegovina has adopted very restrictive position concerning the proof of genocidal intention as dolus specialis of the crimes of genocide, including here acts of ethnic cleansing, Croatia as the applicant could reconsider its own possibilities in prolongation of these proceedings. It continued the suit and the 
Dr. sc. Vladimir-Đuro Degan: Zločin genocida pred Međunarodnim sudom u Haagu Zbornik radova Pravnog fakulteta u Splitu, god. 53, 2/2016., str. 329.-376.

final result was that the Court in its Judgment of 2015 rejected all Croatia's claims together with demands from the Serbian counter-claim. It would be better to grant all the money spent in this costly case directly to victims of international crimes, be they the acts of genocide or not.

Key words: Actus reus; mens rea; dolus specialis; compétence de la compétence; precedents 